\title{
Advancing Water Conservation in Cooling Towers through Energy- Water Nexus
}

\author{
Saeed Ghoddousi ${ }^{1 *}$, Austin Anderson ${ }^{1}$, Behnaz Rezaie ${ }^{1}$
}

${ }^{1}$ University of Idaho, USA

*Corresponding Author: ghod4080@vandals.uidaho.edu

Citation: Ghoddousi, S., Anderson, A. and Rezaie, B. (2021). Advancing Water Conservation in Cooling Towers through Energy-Water Nexus. European Journal of Sustainable Development Research, 5(3), em0161. https://doi.org/10.21601/ejosdr/10952

\section{ARTICLE INFO}

Received: 21 Jan. 2021

Accepted: 13 Apr. 2021

\begin{abstract}
Life without water is not possible on the earth, while modern humans need water not only for drinking, sanitization, and agriculture but also for industrial activities including electricity and cooling generations. Hence, emphasis on water sustainability through different sectors including thermoelectric and cooling plants is an intelligent strategy while the tight connections of water and energy guide study towards energy-water nexus investigations. Cooling towers are equipment for dissipating the excess heat by water evaporation or they hidden gates for wasting water. The objective of the present study is to elaborate on the role of cooling towers in improving environment sustainability by presenting various methods of energy and water modeling, categorizing various methods for modifying water and energy consumptions through past studies and mapping future studies. regarding cooling towers. Presenting a history of energy-water modeling methods of cooling towers, the Markel, the Poppe, and the effectiveness- Number of Transfer Unit (NTU) models, has followed by assessing the environmental impact of cooling towers in the form of excess water consumption, plume, and energy usage. Summarizing and organizing the past efforts for upgrading water management in cooling towers have been in two directions either providing more water supply, or modifications of the cooling tower to use less water. Then the different methodologies for each direction are introduced for further elaborations. This study's practical outcome is proposing the methods of improving water sustainability for any cooling towers from past studies to assist engineers in the industry in modifying cooling towers water consumption. Showing the roadmap for the planning future investigations on the cooling towers based on the past efforts is another outcome of the present study to provide an insight for academia with research interest on cooling towers.
\end{abstract}

Keywords: water conservation, water consumption, water sustainability, cooling tower, wet cooling tower, hybrid cooling tower

\section{NOMENCLATURE}

$a_{f i} \quad$ Surface area of the fill per unit volume of fill

$\mathrm{C}_{\mathrm{pw}} \quad$ Specific heat at constant pressure and at water temperature (J/kg K)

$h_{d} \quad$ Mass transfer coefficient

$f \quad$ Correction factor according to Berman

$M e_{M}$

$M e_{P}$

$M e_{e}$

$\varepsilon$

\section{SUBSCRIPTS}

$\begin{array}{ll}\text { a } & \text { Air } \\ \text { c } & \text { Cold } \\ \text { in } & \text { Inlet } \\ \text { i } & \text { Enthalpy } \\ \text { h } & \text { Hot } \\ \text { m } & \text { Mean } \\ \text { max } & \text { Maximum } \\ \text { min } & \text { Minimum } \\ \text { out } & \text { Outlet } \\ \text { s } & \text { Saturated } \\ \text { ss } & \text { Supersaturated } \\ \text { v } & \text { Vapor } \\ \text { w } & \text { Water }\end{array}$




\section{ABBREVIATIONS}

\begin{tabular}{|c|c|}
\hline APD & Advanced Pinch Design \\
\hline CFC & Chlorofluorocarbons \\
\hline CHP & Combined Heat and Power \\
\hline $\mathrm{COP}$ & Coefficient of Performance \\
\hline ESCO & Energy Service Companies \\
\hline FCC & Fan Cycling Control \\
\hline FMC & Frequency-Modulating Control \\
\hline GWDS & Gravity Water Distribution System \\
\hline HCCCT & Hybrid Closed Circuit Cooling Tower \\
\hline KSD & Kim and Smith \\
\hline MBT & Mercaptobenzothiazole \\
\hline MINLP & Mixed-Integer Nonlinear Programming \\
\hline MSC & Multiple-Speed Control \\
\hline MW & MegaWatt \\
\hline MWNT & Multi-Walled Carbon Nanotubes \\
\hline NREL & National Renewable Energy Laboratory \\
\hline NTU & Number of Transfer Unit \\
\hline $\mathrm{OC}$ & Optimum Control \\
\hline PI & Proportional Iterative \\
\hline PPWD & Parallel Path Wet-Dry \\
\hline PWDS & Pressure Water Distribution System \\
\hline RO & Reverse Osmosis \\
\hline TRNSYS & Transient Systems Simulation \\
\hline VFD & Variable Frequency Drive \\
\hline WESCO & Water Efficiency Service Companies \\
\hline
\end{tabular}

\section{INTRODUCTION}

The cooling tower is one of the key components in industries such as power generation including renewable (geothermal (Hooman, 2010) and solar thermal (X. Li et al., 2017)) and non-renewable (Zhai and Rubin, 2010) power plants, chemical and petrochemical plants (Hansen et al., 2016), refrigeration and air-conditioning plants (Hughes et al., 2011). Thermoelectric generation and its required cooling are responsible for approx. $10 \%$ of the total water demand in the world (Nourani et al., 2019). The role of the cooling tower is dissipating heat from the hot stream of the process into the air (J.-G. Wang et al., 2013) in power plants, district cooling plants, and cooling systems. To address the water scarcity for a sustainable future (in smart cities) cooling towers have to receive special attention. Replacing the evaporation of water for dissipating the heat with another method, or capturing the vapor, or both are the ideas to support water conservation. Considering several cooling towers that are installed already highlights the importance of capturing the vapor and/or reducing evaporation studies.

The design of cooling towers focuses on the water distribution system, fill, and drift elimination. The water distribution system introduces and spreads the process water as evenly over the fill through the use of water canals and nozzles. The fill is a system of packing that delays the fall of water and improves heat transfer, and drift eliminators at the air exit change the direction of airflow to reduce the volume of water transported out (García Cutillas et al., 2017). Within cooling towers, water is lost through three main modes. These modes are drift, blowdown, and evaporation (Schlei-Peters et al., 2018). Drift is the water losses associated with wind, evaporation loss occurs due to the heat transfer taking place, and blowdown is utilized to avoid the buildup of minerals and sediments within the cooling water that may damage other components within the system, and. blowdown is also a byproduct of the evaporation processes increasing the concentration of the minerals (Schlei-Peters et al., 2018).

Oftentimes, cooling towers are oversized, and thus rarely operate at their design points (Cortinovis et al., 2009). One of the primary reasons for oversizing is to ensure proper cooling when ambient temperatures and humidity are high. At high ambient temperature and humidity, it is more difficult to reject heat from a cooling tower. The processing water temperature should be reduced to a specific temperature through the cooling towers, which is designed based on ambient conditions. Most of the time, however, ambient conditions are less extreme, and therefore the large size of the cooling tower is not required in these conditions (Cortinovis et al., 2009).

National Renewable Energy Laboratory (NREL) has provided a protocol for cooling tower measurement and verification to ensure that water savings are properly recorded (Kurnik et al., 2017). It has been intended for energy service companies (ESCOs) and water efficiency service companies (WESCOs) to determine water savings resulting from cooling tower efficiency projects. When measuring both baseline and post-upgrade operations of a cooling tower, it is suggested that multiple seasons of data be used to establish averages. However, a minimum of one season of cooling data is required for analysis. If a flowmeter is being used, the flow of water should be normalized by multiplying the use of water over the cooling season by the sum of the wet-bulb temperature ratios. The sum of wet bulb temperature ratios is found by dividing the historical monthly wet-bulb temperatures for a location by the recorded wet-bulb temperatures during that same month. These ratios can then be added together for all the cooling seasons. The result scales the water-usage during the testing period to historical averages.

The major goal of this study is shedding light on water conservation in cooling towers since water scarcity is a critical problem. The present study's objective is to map the previous studies in improving cooling towers water and energy consumption by categorizing various approaches and explaining their objectives and related attempts. As a foundation for presenting former studies, first different types and configurations of the cooling towers are elaborated then the modeling history of cooling towers are shown, the environmental impacts of cooling towers are described The past studies are concluded in the form of practical methods for improving the cooling towers' energy and water conservations. Also, the direction for future studies is presented. The outcomes of this literature review study assist engineers with practical results and academia to show the future study roadmap, while supporting the environmental sustainability of cooling towers. 

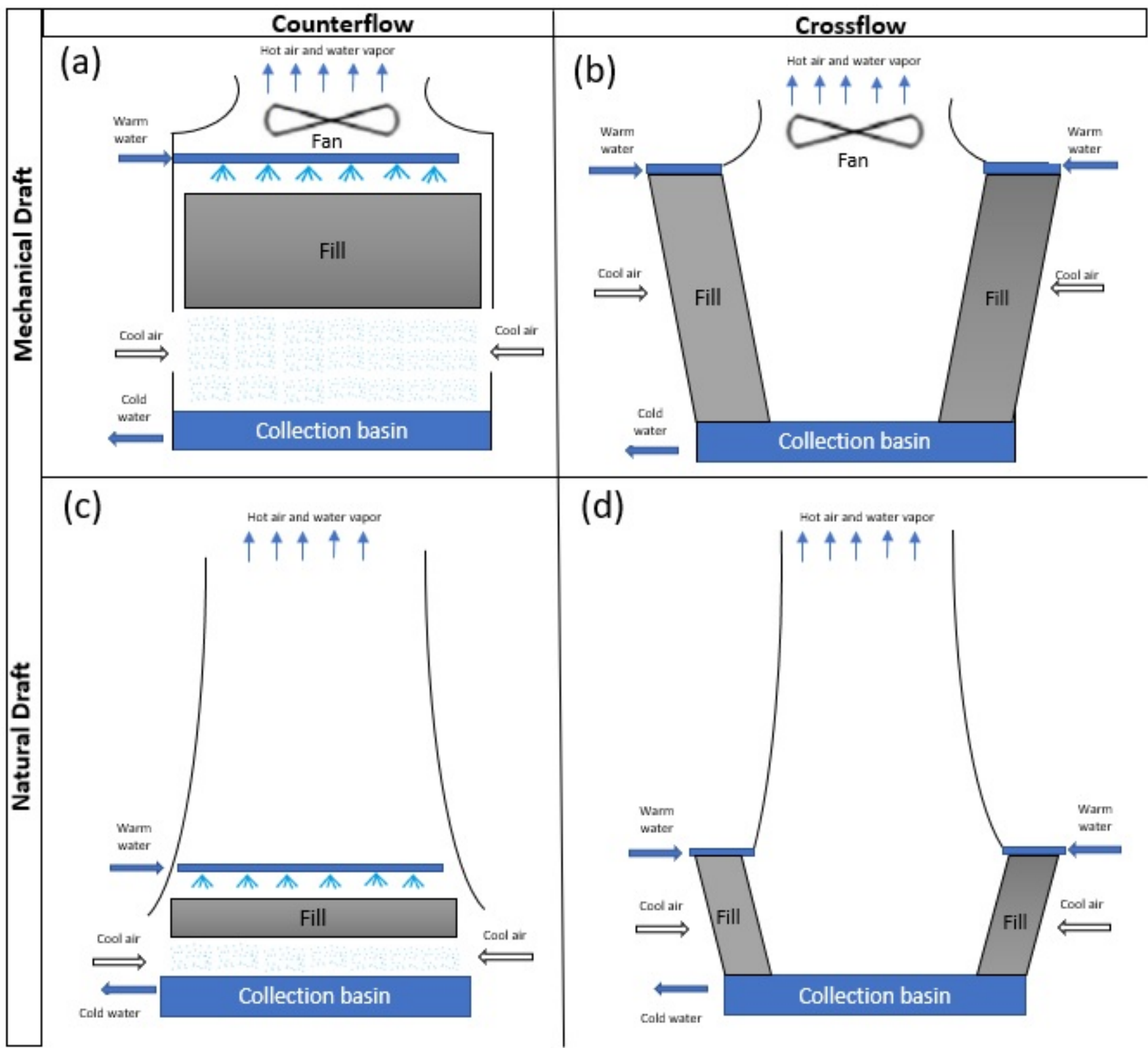

Figure 1. The schematic of different types of wet cooling towers

Table 1. The summary of cooling towers tradeoffs (Martin et al., 2012)

\begin{tabular}{ccccc}
\hline Cooling system & Water withdrawal & Water consumption & Capital cost & Ecological impact \\
\hline Wet cooling tower & Moderate & Intense & Moderate & Moderate \\
\hline Dry cooling tower & None & None & High & Low \\
\hline
\end{tabular}

\section{COOLING TOWERS TYPES}

Cooling towers are classified based on different characteristics, although the following are the major ones:

- Airflow

- Mechanical draft (Figure 1 (a) and (b))

○ Natural draft types (Figure 1 (c) and (d)) (Muangnoi et al., 2006)

- Water consumption

○ Wet (Figure 1),

○ Dry (Figure 2),
○ Combination of wet-dry (hybrid) (Figure 3) (Zavaragh et al., 2016).

Choosing the proper cooling tower for a plant is a balance of different parameters like plant efficiency, capital and operation cost, water consumption, water withdrawal, and environmental impact which are illustrated in Table 1 (Martin et al., 2012).

\section{Wet Cooling Towers}

Wet cooling towers operation is changing water from liquid to vapor to release the excess heat in the cooling cycle (Yang et al., 2019). The thermal performance and stability of the wet cooling tower are better than the dry cooling tower because 
Table 2. The average water consumption of cooling towers in different types of power plants

\begin{tabular}{cccc}
\hline Fuel type & Thermoelectric Technology & $\begin{array}{c}\text { Cooling water consumption } \\
\left(\mathbf{m}^{3} \mathbf{M W h}\right)\end{array}$ & Reference \\
\hline Coal & Steam turbine & $2.1 / 2.13$ & (Sanders, 2015; Scanlon et al., 2013) \\
\hline Coal & Supercritical & $1.5 / 1.3$ & (Zhai et al., 2011) \\
\hline Coal & Integrated gasification combined cycle & $1.44 / 1.14$ & (Ciferno et al., 2010; James et al., 2010) \\
\hline Natural gas & Steam turbine & $2.6 / 2.5-4.4 / 3.12$ & (Advocates, 2008; King et al., 2013; Scanlon et al., 2013) \\
\hline Natural gas & Combined cycle & $0.9 / 0.77$ & (Scanlon et al., 2013; Shuster, 2007) \\
\hline \multirow{2}{*}{ Natural gas } & with carbon capture and sequestration & 1.48 & (James et al., 2010) \\
\hline
\end{tabular}

thermodynamic parameters rely less on ambient temperature (Hu et al., 2018). The advantages of wet cooling towers are:

- Saving energy and costs,

- Reducing Chlorofluorocarbons (CFC)s usage,

- Improving life cycle cost-effectiveness (Xuan et al., 2012).

Wet cooling towers are also categorized by the movement of water and air inside of the cooling tower as follows:

- the crossflow towers: air flows horizontally across the falling water as it shows in Figure $\mathbf{1}$ (b) and (d),

- counterflow: the upward airflow that directly opposes the downward flow of the water providing which is shown in Figure 1 (a) and (c) (Guo et al., 2017).

Since counterflow cooling towers have been used more commonly, there are more studies on this type in comparison with crossflow (Hajidavalloo et al., 2010). The schematic of different types of wet cooling towers is shown in Figure 1.

In wet recirculating cooling tower systems, the warm water from a plant process condenser is pumped to a cooling tower where heat is dissipated to the ambient environment by evaporating water (Deziani et al., 2017). Surrounding ambient air can be forced into the cooling tower by one or more fans to accelerate heat dissipation which results in increasing the temperature of the incoming air (Schlei-Peters et al., 2018). Once the water has been cooled, it can then be returned to the plant process for reuse.

The closed recirculating cooling towers withdraw water, then circulate that instead of discharging (S.-Y. Pan et al., 2018). Significant amount of water gets consume in the cooling towers, particularly freshwater in the power generation plants, depends on the type of fuel and power generation technology (Meldrum et al., 2013). Coal has a high moisture content and contaminants that decreases its combustion properties. A coal-fired power plant requires more electricity for its pollution control operation because a coal-fired power plant releases more pollutants than a power plant that uses natural gas. Reducing the combustion properties and using more electricity in pollution control operation results in thermal efficiency reduction in coal-fired power plant. Also, the combined cycle thermoelectric technology uses waste heat to generate power, which enhances the power plant's thermal efficiency compared with steam turbine technology. Consequently, fuel types and power generation technologies influence the power plants thermal efficiency (Meldrum et al., 2013; Suppes and Truman, 2007). Power plants with lower thermal efficiency convert less thermal energy to electric power, therefore they require more cool water for condensing (Sanders, 2015). Table 2 illustrates the water consumption (loss) of cooling towers in the different thermal cycles. It must be noted that wet cooling towers are not favorable in the region with water shortages due to the high water consumption of them (Sesma Martín and Rubio-Varas, 2017). Water availability is a key parameter in the decision-making of choosing the suitable cooling tower (Peer and Sanders, 2017).

\section{Dry Cooling Towers}

A dry cooling tower depends on convective heat transfer that is governed by the dry-bulb air temperature (Conradie and Kröger, 1996). In a dry cooling tower, heat exchangers are placed in the core of the tower which uses air as the cooling medium, and hot water becomes cold in a closed circulating loop (Wei et al., 2017). Dry cooling is applicable by either mechanical draft or natural draft (Duniam et al., 2018). Figure 2 shows dry cooling towers in the form of a mechanical draft and a natural draft. The dry cooling towers in comparison with wet cooling towers:

- Dissipate less heat in the cooling process,

- Consume less water, therefore,

- Need less maintenance (He et al., 2013)

Therefore, it can be concluded that dry cooling towers are better candidates for regions with water scarcity, while they are less effective.

\section{Hybrid Cooling Towers}

In the 1970s, cooling towers both wet and dry were combined as hybrid cooling towers (Taghian Dehaghani and Ahmadikia, 2017). Therefore, hybrid cooling towers' components have the advantages of both cooling towers (RD Mitchell, 1989). They consume less water while still maintaining a similar heat load rejection capacity. Hybrid cooling towers can be used separately or simultaneously either for water conservation (Rezaei et al., 2010) or plume abatement purposes (Tyagi et al., 2007, 2012; X. Xu et al., 2008). A hybrid cooling tower benefits depend on the heat load, the airflow rate, and the ambient air conditions (Asvapoositkul and Kuansathan, 2014). The performance of hybrid cooling towers was investigated by numerical simulations and experiment on various operation conditions (Asvapoositkul and Kuansathan, 2014). A computational procedure to predict hybrid cooling tower performance in a wide and variable range of working conditions was developed. The outcomes revealed the most important factor in designing the hybrid cooling tower was water to air ratio that was related to the operating condition of the cooling towers. Similarly, the water mass flow rate and air mass flow rate varied from 2.08 $\mathrm{kg} / \mathrm{s}$ to $3.90 \mathrm{~kg} / \mathrm{s}$ and $0.5 \mathrm{~kg} / \mathrm{s}$ to $4 \mathrm{~kg} / \mathrm{s}$, respectively in tests. While implementing the dry cooling tower reduced water 


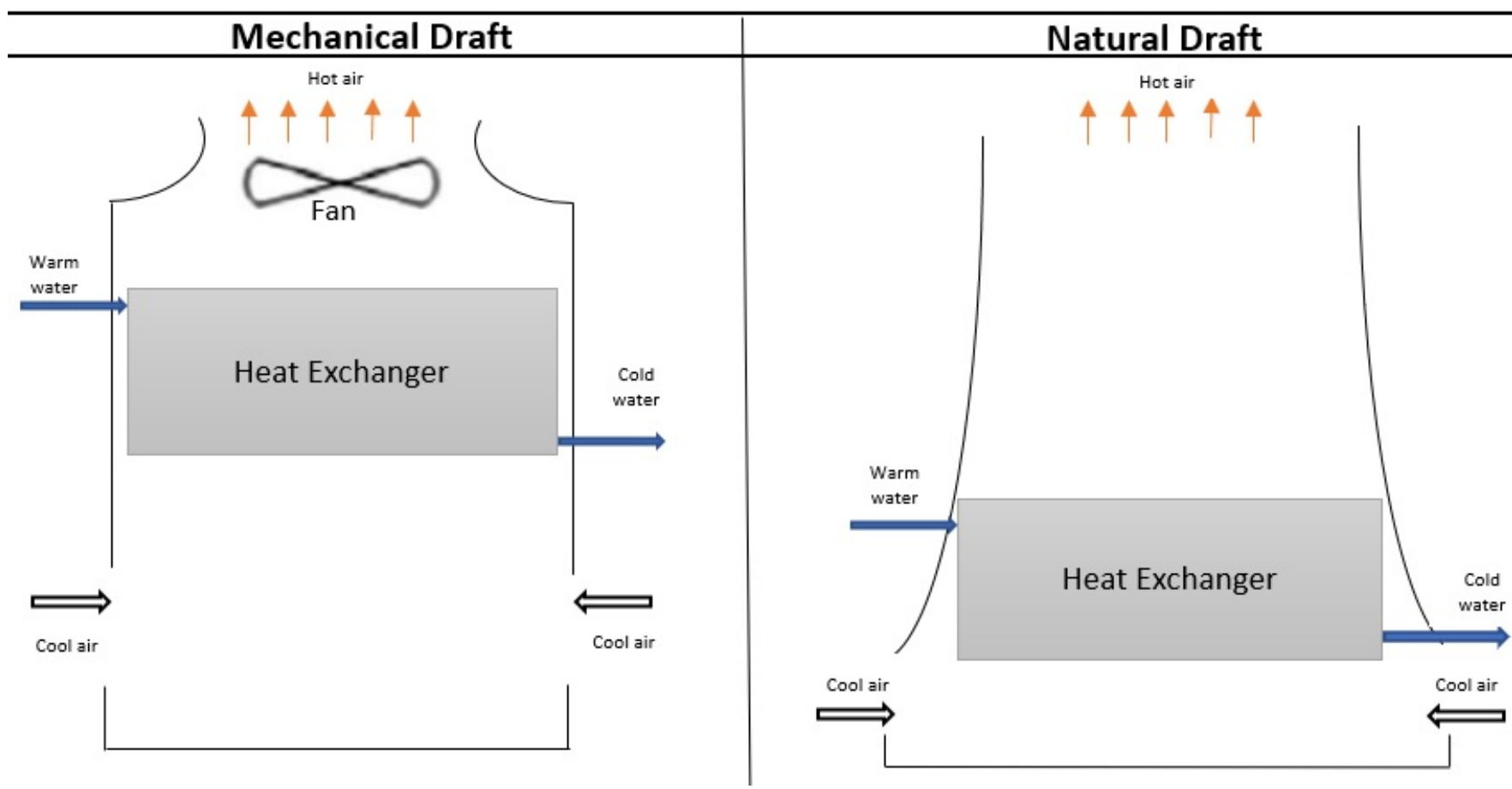

Figure 2. The schematic of natural and mechanical draft dry cooling towers

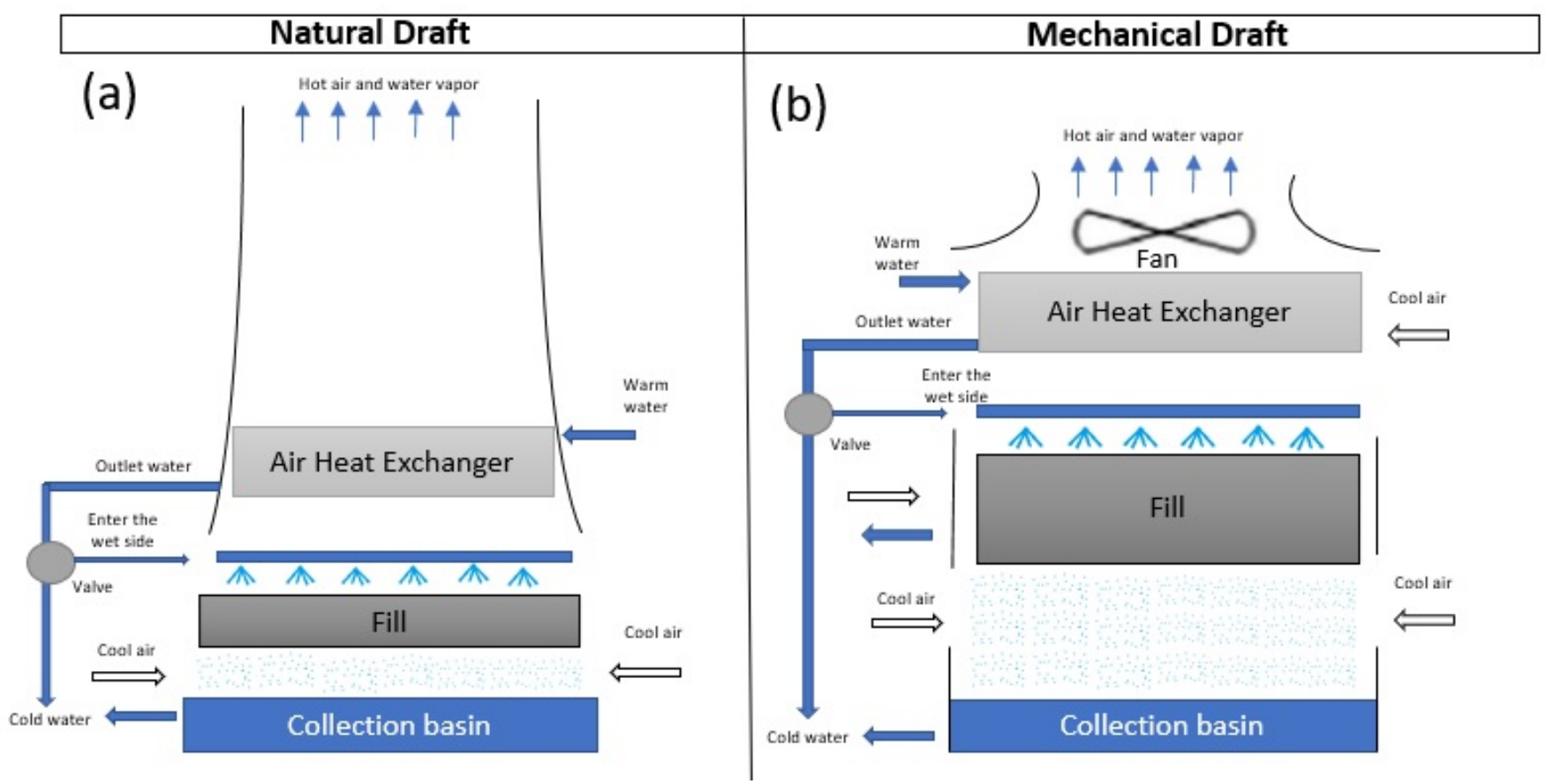

Figure 3. The schematic of natural and mechanical draft hybrid cooling towers

evaporation in compare with wet cooling tower but it increased the energy consumption. Since the pump power consumption in a wet cooling tower was less than fan in a dry cooling tower (similar performance), by increase of using dry cooling tower section, power consumption boosted from $0.14 \mathrm{~kW}$ to $35 \mathrm{~kW}$ (Asvapoositkul and Kuansathan, 2014). The parallel airflow was flowing through both dry and wet sections while the cooling tower load water was running in a series path from the dry cooling tower to the wet cooling tower (Streng, 1998). It was concluded that the performance of dry cooling and wet cooling towers was dependent on the adjustable airflow to each section. Consequently, when a hybrid setup met the cooling demand, the required power was significantly reduced by lowering the airflow to the dry section. Furthermore, the higher fractions of airflow going to the wet cooling tower was followed with a more favorable COP (Asvapoositkul and Kuansathan, 2014). The schematic of different natural draft and mechanical draft hybrid cooling towers are shown in Figure 3.

In a study, the hybrid cooling tower was designed by adding several dry cooling towers units to the existing wet cooling tower at a power plant and a refinery station. The study's outcome led to reduce the water consumption and operational cost in the plant (Nourani et al., 2019). The results showed the total water consumption of the cooling tower at various hybrid 
ratios was reduced to $38 \%$, leading to a cost savings as well (Nourani et al., 2019). In a similar study, by three types of cooling tower system dry, wet, and hybrid in a 660 MW power plant in China the thermodynamic models developed to study the effects of the dry bulb, wet bulb temperature, and humidity on the operation (Hu et al., 2018). The results indicated that implementing hybrid cooling towers reduced $46 \%$ of water consumption compared with a wet cooling tower and reduced 45.84\% fan energy usage compared with dry cooling (Hu et al., 2018). The optimum hybrid cooling tower were designed with wet/dry cooling ration for a $12.5 \mathrm{MW}$ steam power plant in Iran based on the ambient data of the prior five years (Golkar et al., 2019). The optimization was set to find theminimum investment and the minimum water consumption in a hybrid cooling tower. The temperature of the outlet water from cooling tower and the evaporation rate were determined by the ambient condition variations and also changing the fan speed in both dry and wet cooling towers. When the outlet water temperature from the dry heat exchanger was more than $23^{\circ} \mathrm{C}$, the water was conducted to wet cooling tower to provide required cold water (less than $23{ }^{\circ} \mathrm{C}$ ). Otherwise, cooling process was performed without using wet cooling tower to reduce power plant water consumption. When wet cooling towers were not needed, the water losses were zero, therefore the annual decline of power plant water consumption was 1.21 million cubic meter. Besides, by increasing the share of dry side in a hybrid cooling tower, water consumption was significantly reduced. It was shown that usingan optimum designed hybrid cooling tower reduced 63\% water consumption (Golkar et al., 2019).

The flow resistance of the natural draft of a hybrid cooling tower with parallel airside cooling sections of wet and dry cooling was investigated to determine the annual thermal and economic performance in different ambient conditions (Wei et al., 2020). The study was on wet, dry, and hybrid cooling towers coupled with a $660 \mathrm{MW}$ steam power plant. Results indicated the operation costs of hybrid cooling tower was lower than dry and wet cooling towers while the net benefits of $\$ 200 / \mathrm{h}$ in 2010 and $\$ 100 / \mathrm{h}$ in 2018 were attained, respectively (Wei et al., 2020).

An experimental study was conducted by a finned tube instead of a bare tube for increasing the heat transfer surface area to release more excess heatin the dry section of a hybrid cooling tower. The impact of finned tubes in a Hybrid Closed Circuit Cooling Tower (HCCCT) was studied by switching from wet to dry modes depending upon the cooling load. (Sarker et al., 2009). The study showedthe impacts of bare-type copper tubes and finned tubes on the cooling capacity in a hybrid closed circuit cooling tower was $22 \%$ and $26 \%$ increase in the cooling capacity of wet and dry modes, respectively. However, the operation cost was increased due to the higher pressure drop (Sarker et al., 2009). Additionally, the use of finned tubes required only $80 \%$ of the airflow that regular tubes required.

A method of retrofitting existing wet cooling towers to reduce water consumption was introduced by using air-cooled heat exchangers in an existing wet cooling tower (Taghian Dehaghani and Ahmadikia, 2017). The existing wet fill was lowered to make room for the dry section. An airflow control system was introduced for controlling the airflow to the minimum water loss. The system is known as a Parallel Path
Wet-Dry (PPWD) system which is shown in Figure 3 (b). In PPWD system, water flews first into the dry section and then into the wet section. The air streams were in parallel and only mix in the plenum above the dry section. An annual water consumption reduction between $4.3 \%$ to $6.7 \%$ was estimated, depending upon the dry section heat exchanger design by the hybrid PPWD cooling tower in comparison to a wet type.

\section{MODELING STUDIES ON COOLING TOWERS}

Modeling of cooling towers started with Lewis who analyzed the cooling tower thermodynamically in the $20^{\text {th }}$ century (Lewis and K., 1922). Then, Robinson's equations for the cooling tower were developed based on Lewis' work (CS Robinson, 1923). Merkel proposed a model in which enthalpy was potential as the driving force for air-water exchange, heat, and mass convection transfer employing Lewis number (Merkel et al., 1925). Some underestimation of cooling towers sizing existed in Merkel's model (Sutherland, 1983). Bourillot modified the Merkel model about insufficiency to define water consumption over excess simplification of the model (Bourillot, 1983). Poppe and Roger added the heat and mass transfer coefficients for supersaturated and unsaturated air in their model to the Bourillot model and defined a new Merkel number formulation (Poppe and H Rögener -, 1991). Braun et al. and Jaber et al. developed the effectiveness- Number of Transfer Unit (NTU) model and found a method for calculation of the cooling tower performance by improving the Merkel's model (J. Braun et al., 1989; J. E. Braun, 1988; Jaber and Webb, 1989). Both the Merkel and effectiveness-NTU models could accurately predict the outlet water temperature, both were inadequate in the evaluation of the evaporated water flow rate and properties of the outlet air while the Poppe model was able to predict the states of the outlet air accurately (Ke et al., 2019). Finally, Klopper proposed a model based on the Poppe model to calculate the water evaporation rate based on the actual value of the Lewis factor (Johannes Christiaan Kloppers, 2003).

Before further explanations, it must be noted that the wet cooling tower models are defined based on the ambient properties. The thermal performance of wet cooling towers strongly depends on the humidity and temperature of the ambient (Picón-Núnez et al., 2011).

\section{The Merkel Model}

The air and water flow in the counterflow cooling tower are shown in Figures $\mathbf{4}$ and $\mathbf{5}$ where the air is in counterflow with a downwards flowing water stream. These figures show an idealized model of the interface between the water and the air for a counterflow cooling tower filler materials. Figure 4 shows a control volume in the filler. Figure 5 illustrates an airside control volume of the filler shown in Figure 4. Eq. (1) and (2) are obtained from mass and energy balances of the control volumes shown in those figures. The change in the enthalpy of the air-water vapor mixture and the change in water temperature as the air travel distance changes are shown in the Eq. (1), and (2), respectively. The main assumption of the Merkel method is neglecting the evaporation in the water 


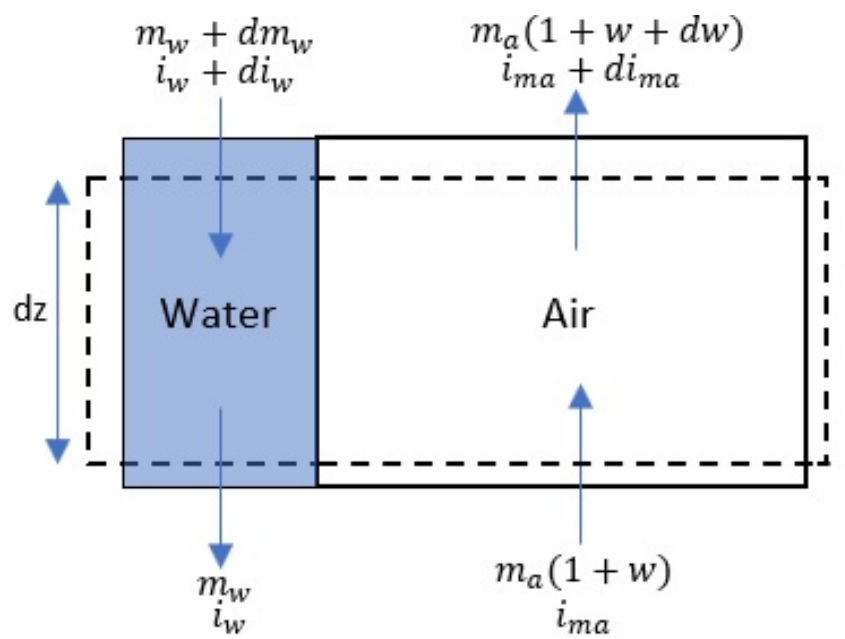

Figure 4. Control volume related to the cross-section of the filler section

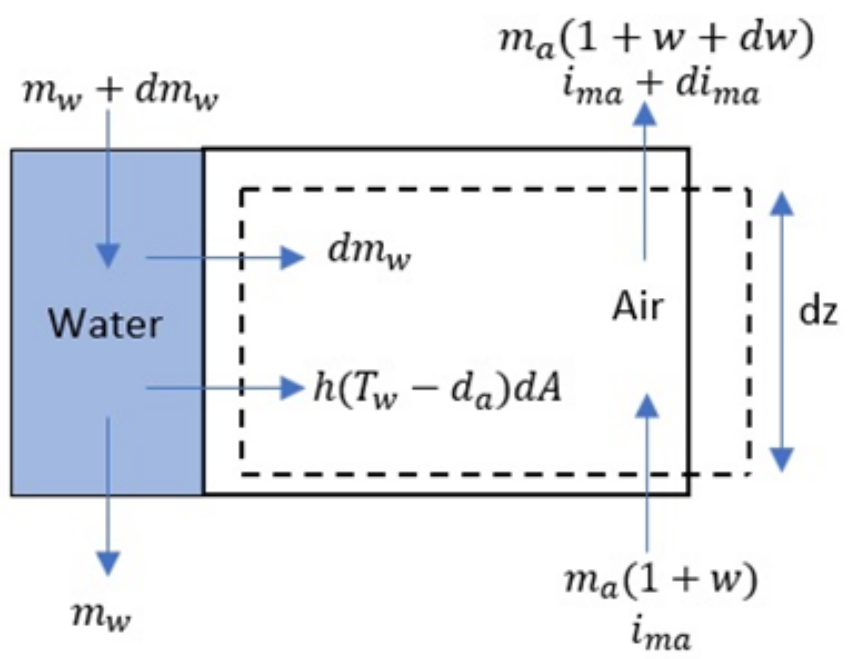

Figure 5. Air volume control in the filling section

mass flow rate $\left(\mathrm{dm}_{\mathrm{w}}=0\right)$. Also, the Merkel number can be obtained Eq. (3).

$$
\begin{gathered}
\frac{d i_{m a}}{d z}=\frac{h_{d} a_{f i} A_{f r}}{m_{a}}\left(i_{m a s w}-i_{m a}\right) \\
\frac{d T_{w}}{d z}=\frac{m_{a}}{m_{w}} \frac{1}{c_{p w}} \frac{d i_{m a}}{d z} \\
M e_{M}=\frac{h_{d} a_{f i} A_{f r} d z}{m_{w}}=\int_{T_{w, o u t}}^{T_{w, i n}} \frac{c_{p w} d T_{w}}{\left(i_{m a s w}-i_{m a}\right)}
\end{gathered}
$$

Here, $i_{m a}$ and $i_{\text {masw }}$ are the enthalpy of the air-vapor mixture per unit mass of dry air and the enthalpy of saturated air at water temperature in $\mathrm{J} / \mathrm{kg}$, respectively. $\mathrm{C}_{\mathrm{pw}}$ is water specific heat at constant pressure and in $\mathrm{J} / \mathrm{kg} \mathrm{K}$. Also, $\mathrm{m}_{\mathrm{w}}$ and $\mathrm{m}_{\mathrm{a}}$ are discharging the water mass and air mass from the cooling tower in $\mathrm{kg}$, respectively. Also, $M e_{M}$ and $h_{d}$ denote transfer coefficient according to the Merkel model and the mass transfer coefficient, respectively. $a_{f i}$ is the surface area of the fill per unit volume of fill in $\mathrm{m}^{2}$, and $T_{w}$ is water temperature in ${ }^{\circ} \mathrm{C}$.

\section{The Poppe Model}

Merkel model has some simplifying assumptions such as:
- considering the Lewis factor relating to heat and mass transfer is equal to 1

- assuming that the air leaving the fill section is saturated with water vapor

- neglecting the reduction of water flow rate by evaporation in the energy balance (Johannes Christiaan Kloppers, 2003)

The Poppe model is developed without the simplifying assumptions of the Merkel model. Thus, the control volumes in Figures $\mathbf{4}$ and $\mathbf{5}$ are still applicable to this model. Kloppers modified the Poppe model by derivation of the original equation to wet cooling towers as shown in Eq. (4) and (5) for unsaturated air conditions and Eq. (8) and (9) for supersaturated air conditions (Johannes Christiaan Kloppers, 2003). When the air becomes saturated before it leaves the fill, the potential for heat and mass transfer still exists because the water temperature is still higher than the temperature of the air. At this point, the excess vapor condenses as a mist and is suspended in the air which leads to having a supersaturated air (Huang et al., 2017). Le $\mathrm{f}_{\mathrm{f}}$ is the coefficient of Lewis, according to Eq. (6) for unsaturated air conditions and Eq. (10) for supersaturated air conditions (Johannes C. Kloppers \& Kröger, 2005). The Merkel number according to the Poppe approach is given by Eq. (7) for unsaturated air conditions and Eq. (11) for supersaturated air conditions.

$$
\begin{gathered}
\frac{d w}{d T_{w}}=\frac{c_{p w} \frac{m_{w}}{m_{a}}\left(w_{s w}-w\right)}{\left.i_{m a s w}-i_{m a}+\left(L e_{f}-1\right)\left[i_{m a s w}-i_{m a}-\left(w_{s w}-w\right) i_{v}\right]-\left(w_{s w}-w\right) c_{p w} T_{w}\right]} \\
\frac{d i_{m a}}{d T_{w}}=\frac{m_{w} c_{p w}}{m_{a}}\left(1+\quad c_{p w} T_{w}\left(w_{s w}-w\right)\right. \\
\left.\frac{\left.i_{m a s w}-i_{m a}+\left(L e_{f}-1\right)\left[i_{m a s w}-i_{m a}-\left(w_{s w}-w\right) i_{v}\right]-\left(w_{s w}-w\right) c_{p w} T_{w}\right]}{2}\right) \\
L e_{f}=0.865^{0.667} \frac{\left(\frac{w_{s w}+0.622}{w+0.622}-1\right)}{\ln \left(\frac{w_{s w}+0.622}{w+0.622}\right)}
\end{gathered}
$$

$\frac{d M e_{P}}{d T_{w}}=$

$$
\begin{aligned}
& \frac{c_{p w}}{\left.i_{m a s w}-i_{m a}+\left(L e_{f}-1\right)\left[i_{m a s w}-i_{m a}-\left(w_{s w}-w\right) i_{v}\right]-\left(w_{s w}-w\right) c_{p w} T_{w}\right]} \\
& \frac{d w}{d T_{w}}= \\
& \frac{c_{p w} \frac{m_{w}}{m_{a}}\left(w_{s w}-w_{s a}\right)}{i_{\text {masw }}-i_{s s}+\left(L e_{f}-1\right)\left(i_{\text {masw }}-i_{s s}-\left(w_{s w}-w_{s a}\right) i_{v}+\left(w-w_{s a}\right) c_{p w} T_{w}\right)+\left(w-w_{s w}\right) c_{p w} T_{w}} \\
& \frac{d i_{m a}}{d T_{w}}=c_{p w} \frac{m_{w}}{m_{a}}(1+ \\
& c_{p w} T_{w}\left(w_{s w}-w_{s a}\right) \\
& \left.i_{\text {masw }}-i_{s s}+\left(L e_{f}-1\right)\left\{i_{m a s w}-i_{s s}-\left(w_{s w}-w_{s a}\right) i_{v}+\left(w-w_{s a}\right) c_{p w} T_{w}\right\}+\left(w-w_{s w}\right) c_{p w} T_{w}\right) \\
& L e_{f}=0.865^{0.667} \frac{\left(\frac{w_{s w}+0.622}{w_{s a}+0.622}-1\right)}{\ln \left(\frac{w_{s w}+0.622}{w_{s a}+0.622}\right)}
\end{aligned}
$$

Where $\mathrm{w}$ is the amount of humidity in the cooling tower in kg. $i_{s s}$ and $i_{v}$ are the enthalpy of supersaturated air per unit mass of dry air and the enthalpy of the water vapor in $\mathrm{J} / \mathrm{kg}$, respectively. Also, $w_{s w}$ and $w_{s a}$ denote the ratio of water saturation at the water temperature and the humidity ratio of 
saturated air at temperature $\mathrm{Ta}$, respectively. Lef is Lewis factor, and $M e_{P}$ is Merkel number according to the Poppe model.

\section{The Effectiveness-(NTU) Model}

According to Jaber and Webb who design cooling towers by effectiveness-(NTU) method, Eq. (12)-(19) are developed (Jaber and Webb, 1989). Eq. (12), and (13) correspond to the differential equation of the heat exchanger. Based on Eq. (12), $\mathrm{m}_{\mathrm{a}}$ can be greater than $m_{w} c_{p w} /\left(d i_{\text {masw }} / d T_{w}\right)$ or less; Thus, $\mathrm{C}_{\max }$ is defined as the maximum amount of these two values, and $\mathrm{C}_{\min }$ is defined as the minimum amount of these two values. Also, Eq. (18) calculates the Merkel number according to the effectiveness-(NTU) approach when the dry air mass flow rate $\left(\mathrm{m}_{\mathrm{a}}\right)$ is greater than $m_{w} c_{p w} /\left(d i_{\text {masw }} / d T_{w}\right)$, and Eq. (19) corresponds to this number when $m_{a}$ is less than $m_{w} c_{p w} /\left(d i_{\text {masw }} / d T_{w}\right)$ (Jaber and Webb, 1989).

$$
\begin{gathered}
\frac{d\left(i_{\text {masw }}-i_{m a}\right)}{\left(i_{\text {masw }}-i_{\text {ma }}\right)}=h_{d}\left(\frac{\frac{d i_{\text {masw }}}{d T_{w}}}{m_{w} c_{p w}}-\frac{1}{c_{p w}}\right) d A \\
\frac{d\left(T_{h}-T_{c}\right)}{\left(T_{h}-T_{c}\right)}=-U\left(\frac{1}{m_{h} c_{p h}}-\frac{1}{m_{c} c_{p c}}\right) d A \\
C=C_{\text {min }} / C_{\text {max }} \\
\varepsilon=\frac{Q}{Q_{\text {max }}}=\frac{m_{w} c_{p w}\left(T_{w, \text { in }}-T_{w, o u t}\right)}{C_{\text {min }}\left(i_{\text {masw }, \text { in }}-f-i_{\text {ma,in }}\right)} \\
f=\left(i_{\text {masw out }}+i_{\text {masw }, \text { in }}-2 i_{\text {masw }, m}\right) / 4 \\
N T U=\frac{1}{1-C} \ln \frac{1-\varepsilon C}{1-\varepsilon} \\
M e_{e}=\frac{c_{p w}}{d i_{\text {masw }} / d T_{w}} N T U \\
M e_{e}=m_{a} N T U / m_{w}
\end{gathered}
$$

Here, $\varepsilon$ and $f$ are the effectiveness ratio and a Berman's correction factor, respectively. $i_{\text {masw, } m}$ is the enthalpy of saturated air at the mean water temperature in $\mathrm{J} / \mathrm{kg}$. $T_{w, \text { in }}$ and $T_{w, o u t}$ denote the inlet and outlet water temperature of cooling towers in ${ }^{\circ} \mathrm{C}$, respectively. $\mathrm{U}$ is overall heat transfer coefficient in $\frac{W}{m^{2 \circ} \mathrm{C}}$. Q is the heat transfer rate in W. NTU shows the number of transfer units, and $\mathrm{Me}_{\mathrm{e}}$ is Merkel number according to Effectiveness-(NTU) model. The Merkel, Poppe, and e-NTU models have been implemented in many cooling towers' studies with different objectives. Based on the modeling types and objectives, research papers have been summarized in Table 3, to map the applications of each cooling tower modeling methods since 2003.

Several studies were conducted to compare the Merkel, Poppe, and e-NTU models through experimental observation under test conditions. The summary of those studies can be as the following categories:

- Air outlet temperature: When the outlet air from the cooling tower was saturated, Merkel and e-NTU models were capable of predicting the temperature of that, while the Poppe model did not need any assumption for estimation of the outlet air temperature from the cooling tower (Johannes C Kloppers and Krö Ger, 2005).

- Water outlet temperature: When the draft in the cooling tower was the same, the outlet water temperature from the cooling tower in the three models were the same. A small difference in the outlet water temperature from the cooling tower was observed in Merkel and Poppe models over the outlet air from the cooling tower since outlet air assumed saturated in the Merkel model (Ayoub et al., 2018).

- Heat rejected: The loss of water due to evaporation in the cooling tower reduced the water outlet mass flow rate, which was ignored in the energy equation in the Merkel and e-NTU models while it was seen in the Poppe model. The estimated heat rejection rate by the cooling tower was larger by the Poppe model in comparison with Merkel and e-NTU models (Ayoub et al., 2018).

- Evaporation rate: The water evaporation rate in the cooling tower was underestimated by the Merkel model compared to the Poppe model (Grange, 1994). Since evaporation was an important factor in designing the hybrid cooling towers, using the Poppe model was preferred (Ayoub et al., 2018; M Roth, 2001).

- Lewis factor: The Poppe model proposed a reliable equation to determine the Lewis factor value (Johannes C Kloppers and Krö Ger, 2005). While in the Merkel model the Lewis factor was a constant number of 1 . Most researchers believed that Merkel's assumption was not accurate since the Lewis factor was between 0.6 to 1.3 (Hassler, 1999).

\section{ENVIRONMENTAL IMPACT}

Using wet cooling towers has some negative impacts on the environment. However, using wet cooling towers reduces the emission of CFCs into the atmosphere, which are strongly harmful to the Ozon layer. The major categories that wet cooling towers cause negative impacts on the environments are with respect to water, plume, and energy.

\section{Water}

The wet cooling towers are widely used and considering the high-water consumption in this type of cooling towers, and they are not desired in zones with water resources limitation (Ma et al., 2018). Many ideas have been proposed and investigated as mitigation strategies for resolving water consumption issues. All approaches are in two categories:

- Improving the design parameters, operations, structure of the cooling towers to reduce water consumption. Many of these studies are explained under improving water conservation in the present study.

- Focusing on the circulating water in the cooling tower for lesser evaporation through different approached.

Some of these methods have been detailed in improving water conservation. 
Table 3. Modeling approaches and objectives of wet cooling towers studies

\begin{tabular}{|c|c|c|}
\hline Study & Objective & Model \\
\hline Irok et al. (2003) & Performance analysis & Merkel \\
\hline Khan et al. (2004) & Performance analysis & Effectiveness-(NTU) \\
\hline Söylemez (2004) & Performance optimization & Effectiveness-(NTU) \\
\hline Papaefthimiou et al. (2006) & Performance analysis & Merkel \\
\hline Kranc (2007) & Performance analysis & Merkel \\
\hline C. Ren (2006) & Model improvement & Merkel \\
\hline Jin et al. (2007) & Model improvement & Merkel/Effectiveness-(NTU) \\
\hline Qi and Liu (2008) & Performance analysis & Poppe \\
\hline Williamson et al. (2008) & Performance analysis & Merkel \\
\hline C. Q. Ren (2008) & Performance analysis & Effectiveness-(NTU) \\
\hline Tyagi et al. (2008) & Cost optimization & Effectiveness-(NTU) \\
\hline Klimanek and Białecki (2009) & Model analysis comparison & Poppe \\
\hline Marmouch et al. (2009) & Performance analysis & Effectiveness-(NTU) \\
\hline Lucas et al. (2009) & Performance analysis & Merkel \\
\hline Rubio-Castro et al. (2011) & Cost optimization & Poppe /Merkel \\
\hline T.-H. Pan et al. (2011) & Performance optimization & Merkel \\
\hline Picón-Núnez et al. (2011) & Design optimal Cooling tower & Effectiveness-(NTU) \\
\hline Smrekar et al. (2011) & Performance analysis & Poppe \\
\hline Rao and Patel (2011) & Performance optimization & Merkel \\
\hline Gololo and Majozi (2012) & Water consumption optimization & Poppe \\
\hline Picardo and Variyar (2012) & Model improvement & Merkel \\
\hline T. Pan et al. (2013) & Performance optimization & Merkel \\
\hline Grobbelaar et al. (2013) & Performance analysis & Merkel \\
\hline Khamis Mansour and Hassab (2014) & Performance analysis & Effectiveness-(NTU) \\
\hline Hernández-Calderón et al. (2014) & Model improvement & Poppe \\
\hline Nasrabadi and Finn (2014a) & Performance analysis & Effectiveness-(NTU) \\
\hline Nasrabadi and Finn (2014b) & Performance analysis & Merkel \\
\hline Uzgoren and Timur (2015) & Performance optimization & Poppe \\
\hline Y. Wang et al. (2015) & Performance analysis & Poppe \\
\hline Y.-J. Xu et al. (2015) & Performance analysis & Merkel \\
\hline Keshtkar \& Mehdi Keshtkar (2016) & Performance optimization & Poppe \\
\hline Singh and Das (2016) & Performance optimization & Merkel \\
\hline Singla et al. (2016) & Performance optimization & Merkel \\
\hline Llano-Restrepo and Monsalve-Reyes (2016) & Model improvement & Merkel \\
\hline Qi et al. (2016) & Performance analysis & Poppe \\
\hline Singh and Das (2017) & Performance optimization & Merkel \\
\hline Sharqawy et al. (2017) & Performance analysis & Effectiveness-(NTU) \\
\hline Gilani and Parpanji (2017) & Performance analysis & Poppe \\
\hline Huang et al. (2017) & Performance analysis & Poppe \\
\hline Y. Li et al. (2017) & Performance optimization & Poppe \\
\hline Zhou et al. (2017) & Performance analysis & Poppe \\
\hline Ayoub et al. (2018) & Model improvement & Merkel/ Poppe/ Effectiveness-(NTU) \\
\hline Mishra et al. (2019) & Performance analysis & Merkel \\
\hline González Pedraza et al. (2018) & Model improvement & Merkel \\
\hline Liao et al. (2019) & Performance optimization & Poppe \\
\hline Jes' et al. (2019) & Model improvement & Poppe \\
\hline Ke et al. (2019) & Performance analysis & Merkel \\
\hline Gilani et al. (2019) & Performance optimization & Poppe \\
\hline
\end{tabular}

\section{Plume}

Cooling towers have environmental impacts by changing the ambient conditions, such as making visible plumes (Lindahl and Jameson, 1995) and releasing hazardous materials (Isozumi et al., 2005). When a wet cooling tower releases the moisture, it mixes with cooler atmospheric air while the vapor closely approaches the saturation point, the plume moisture condenses quickly and generates a visible plume (Michioka et al., 2007). Visible plume is not considered air pollutant but sometimes contains minerals and chemicals that can be hazardous (Meroney, 2006). For safety purposes, some countries have regulated the visible plume by cooling towers (Mantelli, 2016). Using hybrid towers instead of evaporative towers reduces the plume by enhancing the performance of cooling towers (Tyagi et al., 2012).

The fog harvesting and Atmospheric Water Harvesting (AWH) for capturing the vapor to produce water were new approaches for plume abatement (Ghosh and Ganguly, 2019; Kim et al., 2020). Experimental data from outlet fog harvester systems demonstrate that the rate of water collection in cooling tower fog harvester was 3 to 5 times more than atmospheric air fog harvester due to a high relative humidity $(\mathrm{RH})$ level in cooling towers. Moreover, the fog source in 
cooling towers was more permanent than atmospheric air in providing sufficient fog for harvester during the year (Ghosh and Ganguly, 2018). Zapping the fog with the beam charged particles (ions) of electrically has improved capturing water droplets from fog harvester by directing droplets to the storage in a low-cost and low-energy method for collecting of $20 \%$ to $30 \%$ of wastewater in cooling towers (Damak and Varanasi, 2018).

\section{Energy}

Using a Variable Frequency Drive (VFD) fan saves energy in cooling towers which have been studied as a Proportional Iterative (PI) feedback controller with a temperature zone setting to manage the water outlet temperature (C. C. Chang et al., 2015). The goal was to reduce energy consumption and reduce or eliminate frequent on/off fan switch that was typical in cooling towers. The control strategy reduced energy consumption by $38 \%$ within the simulations and result was validated by using the experimental data. The study of seasonal climate change impact on the cooling tower performance for reducing its power consumption by using VFD reduced up to $60 \%$ of annual power consumption in different weather conditions (Pontes et al., 2019). A novel counterflow cooling tower that utilizes a VFD fan, a by-pass loop equipped with microfilters and UV lights was proposed in a study (T.-B. Chang and Lin, 2016). UV lights kept the water at cleaner levels and reduced required blowdown water in the cooling tower. The results of the experiment indicated that at 50\% capacity, the upgraded cooling tower had an energy savings of $76 \%$ with an overall water savings of $23 \%$ in comparison with the original design, a single-stage fan and no water filtration system (T.-B. Chang and Lin, 2016).

\section{WATER CONSERVATION}

To advancing the technology of the cooling towers for reducing water consumption studies with different approaches have been completed. Some of the studies were focusing on advancing the structure of cooling tower, some aiming at operation parameters, and some finding more water. The methodologies for the investigations were in a wide range including experiment, modeling, simulation, and optimization, and modifications.

In the following paragraphs, the major studies have been classified and elaborated. Finally, the methods of water consumption reduction in wet cooling towers have been summarized.

\section{Water Focus}

The circulating water is the medium that carries the cooling and exchanges it for the heat in the buildings in a cooling cycle. The cooling load and the volume of circulating water needs to be adjusted regularly to maintain the cooling performance of the cooling cycle. The lost water due to evaporation in blowdown, and piping leakages must be compensated via make-up water in cooling towers (Botermans and Smith, 2008). Filtration of water is a widespread practice in the industry to soften the water to reduce the make-up water and protect equipment and pipes from fouling and corrosion. The excess water consumption and maintenance of equipment are costly for any energy/cooling plant. Also, governmental incentives are always an effective means for enticing customers to adopt water-saving methods. Generally, various options available for reducing make-up water within wet cooling towers are as follow (Stahl et al., 2015):

- Soft water make-up: removing calcium and magnesium, which are two main formers of scale. This reduces blowdown requirements while increases the pipe corrosion and the cost of producing make-up water,

- Acid Feed: increasing solubility of calcium and magnesium for allowing more cycles of concentration. Although the acid may present a safety concern or corrosion,

- Reverse Osmosis (RO) Concentrate: blending with potable water for make-up,

- Rainwater: collecting and using rainwater as make-up water, some anti-bacterial process may be required,

- Air Handling Condensate: replacing other equipment in large quantities of condensate,

- Fixing Leaks: repairing leaks always reduce water usage. They are wasteful and oftentimes can be overlooked if small, but their waste adds up over time.

A relatively new type of cooling tower known as a water-jet cooling tower was used for the experiment and numerical simulations study (Muangnoi et al., 2014). It was designed with a significant advantage over traditional wet cooling towers for contaminated water such as seawater or oil-water mixtures. In this study, the packing material was substituted with fine water droplets, made from special high-pressure nozzles (Muangnoi et al., 2014). The thermodynamical study results on heat rejection load, wet-bulb temperature, water to air ratio, tower spray zone height, droplet diameter, discharge droplet velocity, and air velocity in water-jet cooling tower showed that the droplet was diameter increased while exergy efficiency was decreased. By the increase of water to air ratio, the exergy efficiency for a smaller droplet size increased while the heat transfer decreased. The feasibility of using seawater instead of freshwater in circulating wet cooling tower in an experimental work showed the impact of saltwater concentrations on the cooling tower performance (Qi et al., 2016). The study presented a valuable theoretical basis for developing seawater cycling instead of freshwater usage which causes to decrease $9.86 \%$ of the cooling tower performance (Qi et al., 2016). In another study, the effect of thermophysical properties of seawater on the thermal performance of the cooling tower caused efficiency reduction of the cooling tower for 5-20\% (Sharqawy et al., 2011).

The study of water harvesting from cooling towers fog was conducted in an experiment by mounting woven metal meshes at the outlet plane of the cooling tower cell. The fog droplet capture efficiency was analyzed by using different mesh configurations. Varying the geometry of the net frame and changing the spacing between adjacent wires in the woven mesh led to the total water reduction by $40 \%$ in a $500 \mathrm{MW}$ power plant in the optimal case (Ghosh et al., 2015).

The influence of the wettability of a mildly hydrophilic metal mesh for fog harvesting purposes in cooling towers was 
experimentally investigated on a small scale. The outcome indicated that from $8 \%$ to $23 \%$ of water content in the fog flow stream was collected (Ghosh et al., 2020).

Multi-walled carbon nanotubes (MWNTs) and nanoporous graphene nanoparticles within a cooling tower were investigated experimentally to understand the effects on energy and water conservation performance of a mechanical wet cooling tower (Askari et al., 2016). The cooling tower thermal efficiency increased by dispersing nanoparticles in water which enhanced its water thermal conductivity. Therefore, the heat transfer increased through the cooling tower. For inlet water temperatures of $40^{\circ} \mathrm{C}$, the use of MWNTs and nano-porous graphene nanoparticles with a $0.1 \%$ mass concentration caused water reduction by $10 \%$ to $19 \%$. The water saving was due to the increase of sensible heat effect and reduction in the latent heat effect. Reduction in the latent heat effect was due to the surface tension change of water as nanoparticles were created resistance against evaporation (Askari et al., 2016). Another experimental study on the performance of cooling towers in six different beds by using nanofluid showed the metal reticular bed as the most suitable bed when using nanofluids because using $\mathrm{ZnO}$ /water nanofluid instead of pure water in the cooling tower improved the thermal efficiency of the tower up to $9.45 \%$ (Imani-Mofrad et al., 2016). However, the economic analysis of this idea, particularly for largescale cooling towers, hazardous impacts of using nanofluids in the water, and the feasibility of performing in the real plant were neglected by the authors.

The effects of increasing the cycles of concentration (cycles of concentration refers to the concentration of dissolved solids in the cooling tower water) within a power plant cooling system for reducing water consumption were investigated by increasing the cycles of concentration in blowdown which led to overall water usage reduction (Rahmani, 2017). The used water was flew through pretreatment, $\mathrm{pH}$ adjustments, chlorination control, and adding inhibitors for improving the quality of water for reusing. It was concluded that despite the treatments, phosphate deposits were observed at higher cycles of concentration. Corrosion and scale control using MBT and $\mathrm{ZnSO}_{4}$ effectively were reduced corrosion in the carbon steel and brass pipes of the heat exchangers. Increasing the cycles of concentration from 6.5 to 9 resulted a water savings of $1.1 \times$ $10^{6} \mathrm{~m}^{3}$ of water per year while cooling requirements were satisfied.

A lab-scale experimental study was conducted to recover evaporated water in the cooling tower by implementing an independent cold-water circulating loop through an array of copper tubes on both sides of the tower, led to the capture of $11 \%$ of vapor. Also, a combination of copper tubes assisted with metal foams improved the result (Pozzobon et al., 2016).

\section{Cooling Towers Modifications}

To capture the vapor out of the cooling tower, a design was utilized for cooling sprays of water drawn by pumps from the bottom of the cooling tower to condense water vapor that flew under vacuum conditions through the vertical channel. The study was on a wet cooling tower which was equipped with an air to air heat exchanger to cool the hot and humid exiting air (Deziani et al., 2017). When the warm-wet air out of the tower was cooled through heat exchanger by an auxiliary fan more condensed water was collected through the cooling tower. $35.4 \%$ of evaporation was saved when the temperature difference between the warm humid air and the cooler ambient air was $15^{\circ} \mathrm{C}$. At a temperature difference of $3^{\circ} \mathrm{C}$, water savings was $15.1 \%$.

TRNSYS (Transient Systems Simulation) was used for modeling, simulation, and evaluation of a cooling tower to study its performance and water loss in four control strategies and six different drift eliminators with two different water distribution systems. The control strategies were Fan Cycling Control (FCC), Multiple-speed fan motor control (MSC), Frequency-modulating control (FMC), and Optimum Control (OC) (García Cutillas et al., 2017). The two different distribution systems were the Pressure Water Distribution System (PWDS) and Gravity Water Distribution System (GWDS). FCC was a capacity control method on cooling towers that kept the system working until the thermostat sent a signal once the hotel's set-point temperature was reached. MSC strategy-controlled outlet-water temperature- by adjusting the suitable fan rotational speed in three stages of velocity to meet the set-point value. FMC used VFD coupled with a standard fixed-pitch fan to control outlet-water-temperature by modifying the fan rotational speed in the various stages (more than three stages compared to MSC). This work also presented the new strategy called $\mathrm{OC}$ to find an optimum operating point for a coupled chiller and cooling tower. Three of the drift eliminators were composed of a zig-zag structure and fiberglass plates separated at distances of 55, 37, and 30 $\mathrm{mm}$, respectively. The remaining drift eliminators utilized a plastic honeycomb structure, a $45^{\circ}$ tilted rhomboid mesh, a $45^{\circ}$ tilted lower half, and a $135^{\circ}$ tilted upper half. The results concluded that the best FCC control strategy operation for reducing water loss was $\mathrm{FMC}, \mathrm{OC}$, and MSC following close behind. There were no substantial benefits between the controls due to most of the water loss occurring in blowdown (70\%) while only $0.3 \%$ accounted for drifting. Also, the annual energy cost savings in the selected hotel in the southeast region of Spain was up to $3240 €$ by using the FMC control method. (García Cutillas et al., 2017).

The heat transfer characteristics and pressure drop of a cooling tower were studied theoretically and experimentally (Naphon, 2005). The experiments were testing the changes in the inlet/outlet air flow rate and inlet temperature and flow rate of water. It was found that increasing the airflow rate into the cooling tower resulted in decreased exiting temperature and decreased outlet water temperature (Naphon, 2005). However, the outlet air temperature approached a minimum amount as the airflow was increased, and the pressure drop across the cooling tower rapidly was increased as the airflow was increased in the tower (Naphon, 2005).

A study of hybrid cooling towers concerning water conservation was conducted by numerical simulation and experiment on parallel and series configurations of a hybrid system in Tabriz Refinery (Tabriz, Iran) (Rezaei et al., 2010). Based on the heat exchanger area of the refinery, the water consumption reduction was between $37 \%$ to $23 \%$ during the summer months for the series and parallel configuration, respectively. Additionally, the payback period for recovering the costs of the upgrades was around seven years for series configuration, while the parallel configuration did not return 


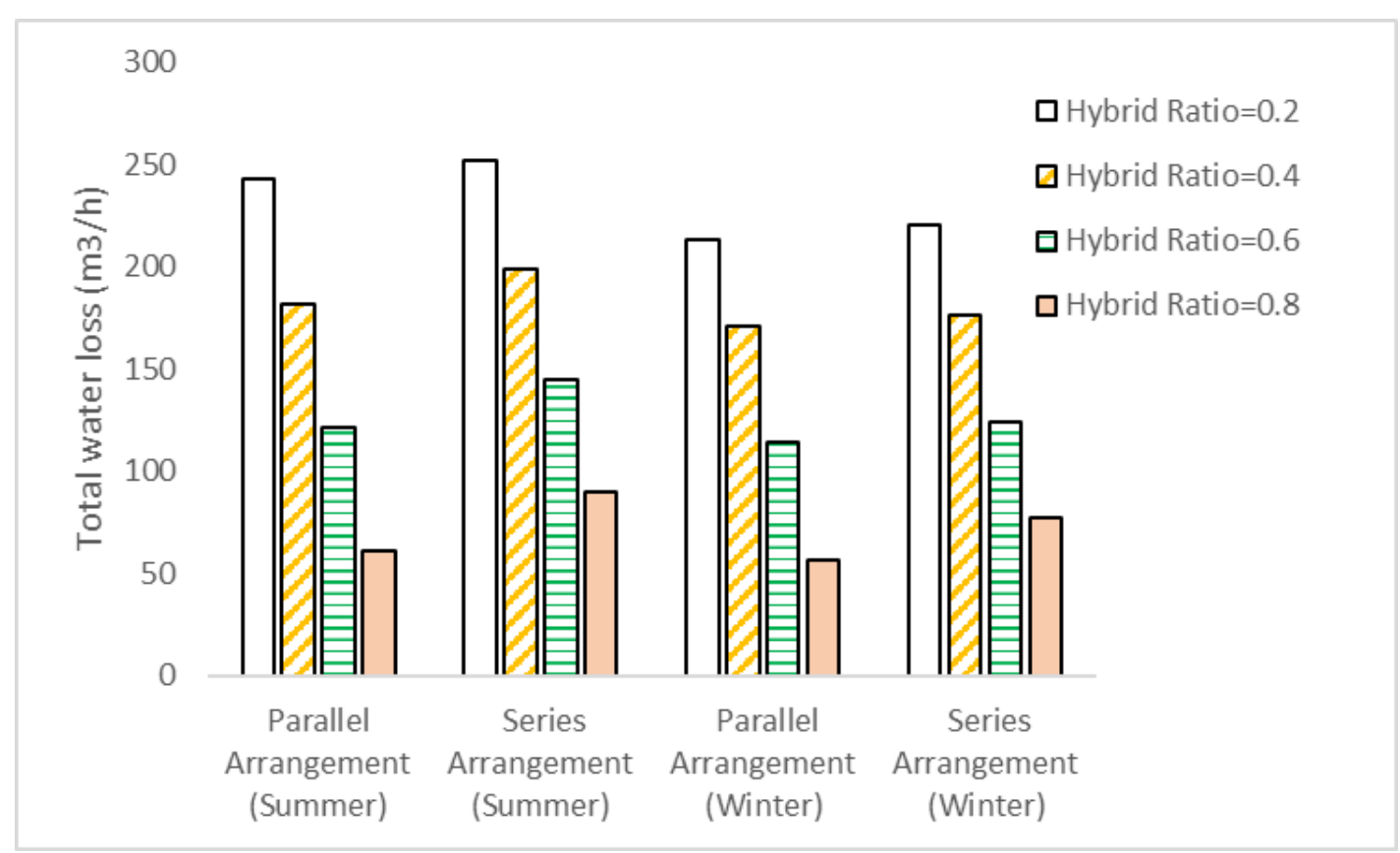

Figure 6. The impact of heat-exchangers arrangement and hybrid ratio on water loss in different seasons at Tabriz refinery plant (Rezaei et al., 2010)

the initial investment. The impact of heat-exchangers arrangement and hybrid ratio on water loss in different seasons at Tabriz refinery plant is shown in Figure 6 (Rezaei et al., 2010). The method of retrofitting an existing wet cooling tower into a hybrid cooling tower with PPWD configuration to reduce make-up water was developed in unit five of the Isfahan (Isfahan, Iran) thermal power plant (Taghian Dehaghani and Ahmadikia, 2017). The goal was to modify the system with minimal effort from the plant personnel labor and cost. The first hybrid used the existing wet towers packing in the same place, while the second one lowered the packing by $1.4 \mathrm{~m}$ to increase the dry section cooling area. Under identical scenarios, the first hybrid setup lowered water consumption by $7.0 \%$ while the second setup, with the larger fraction of total cooling, lowered water consumption by $9.4 \%$ (Taghian Dehaghani and Ahmadikia, 2017).

\section{Optimization Approach}

Optimization as a tool for finding the optimum parameters for the ideal performance has been applied in some cooling tower studies. It should be noted that the optimization of cooling towers and related systems by using air volumetric flow and cooling water flowrate as parameters have three main shortcomings:

- Optimization models often are assumed that process parameters can be modified at any time. Adjustments in process parameters of existing cooling towers require input from operators and equipment manufacturers.

- Fluctuations in environmental conditions are often disregarded.

- There is a lack of systematic identification and assessment of efficiency measures (Schlei-Peters et al., 2018).
A dynamic model was developed to determine the impact of air temperature and humidity ratio in a power plant's cooling tower performance. The 24-hours information of the ambient weather condition, cooling tower water temperature, and its water mass flow rate have was collected to develop a dynamic model. The model was developed based on Poppe model for unsaturated and supersaturated air conditions. (Dhorat et al., 2019). Three objective functions were defined for minimizing operating cost, minimizing the accumulation of water in the tank, and minimizing makeup water flowrate. The results indicated that the makeup water flow rate could be reduced up to $57 \%$ while the costs and energy usage were at minimum possible value (Dhorat et al., 2019). Optimization of a cooling tower in $90 \mathrm{~kW}$ pilot power plant for minimal operating cost by considering fan's speed, make-up water mass flow rate, and valve positions were conducted (Cortinovis et al., 2009). It was observed that the outlet temperature of the cooling tower had to keep as high as the heat load to minimize the cost of system. The most economically minimizing action was to increase the cooling tower water mass flow rate when the load demand was increased and then increase the fan speed by an increase of cooling demand. The reduction in water and energy consumption in the cooling tower was estimated to save $\$ 0.05$ per hour in an optimized pilot plan. The worst scenario was using additional makeup water in the cooling tower which led to a $\$ 0.68$ per hour increase in operating cost compared with the non-optimal scenario (Cortinovis et al., 2009).

The mathematical model for designing a sustainable natural draft wet cooling tower was developed to estimate water consumption as a function of the power plant location in Spain (Guerras and Martín, 2020). The objective functions were defined to find the optimum water consumption, tower size, and cost as a function of humidity, temperature, and atmospheric pressure for different power plant sizes ranged from 40 to $450 \mathrm{MW}$. The study has compared the effect of 


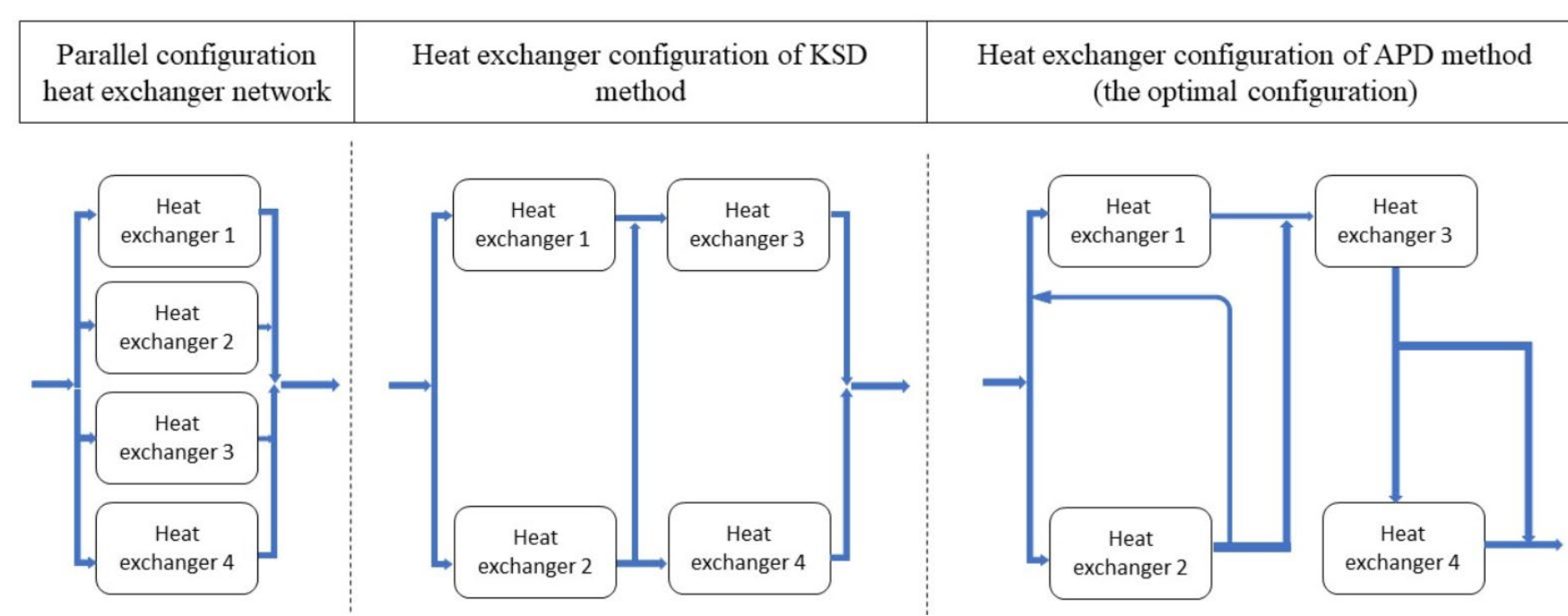

Figure 7. Different heat exchangers network configurations (Panjeshahi et al., 2009)

different weather conditions in designing natural draft of wet cooling tower to reduce water consumption in power plants. The outcomes showed a reasonable agreement between the calculated results and the practical ones, plus the higher level of temperature and humidity led to higher water consumption in wet cooling towers. A power plant in the southeast region of Spain with higher temperature and humidity range consumed around $2 \mathrm{~L} / \mathrm{kWh}$ water, while a similar plant in the northwest of Spain with lower temperature and humidity used about 1.5 $\mathrm{L} / \mathrm{kWh}$ water at the same time (Guerras and Martín, 2020).

The optimization of a cooling water system using mixedinteger nonlinear programming (MINLP) model was performed to reduce water consumption, improve the system operation, and reduce the capital cost of a cooling network using series, parallel, as well as combined series and parallel configurations (Liu et al., 2019). When their MINLP optimization algorithm was employed, the combined series and parallel configuration had minimized the cost (Liu et al., 2019).

A cooling tower using Advanced Pinch Design (APD) to allow for maximum amounts of heat transfer to occur within a system optimized. The APD algorithm let interaction between the cooling tower performance and heat-exchanger network configuration to be considered simultaneously. The objective function was to minimize the cooling tower annual cost which was depending on water consumption, pump power consumption, cooling tower approach temperature, and the ambient wet bulb temperature. In the traditional dry cooling system, parallel configuration was used in heat-exchangers network. However, APD suggested heat exchangers network for the minimum energy and water consumption by maximizing water re-use in the cooling tower. Figure 7 shows the parallel, KSD method, and APD method configuration of the heat exchangers network. APD arrangement was determined as an optimal heat exchanger network in this study because APD provided the minimum annual cost for the cooling tower compared with parallel arrangement an KSD method arrangement. Optimal heat-exchanger arrangement was achieved through an advanced synthesis algorithm using pinch point temperature in heat-exchangers network with four units. The synthesis algorithm adjusts water inlet temperature, water outlet temperature, and pinch point temperature to minimize the cooling tower total annual cost as well as its water consumption. In comparing APD to another optimization algorithm known as the Kim and Smith (KSD) method costs were decreased from $\$ 72,000$ per year and $\$ 59,000$ per year for the conventional and KSD systems respectively, to $\$ 52,000$ for the APD system. The APD algorithm was then modified to optimize for minimal make-up water, which resulted in costs of $\$ 39,000$ per year while $46 \%$ of make-up water was saved (Panjeshahi et al., 2009).

The optimizing heat transfer in a cooling tower by studying the water distribution system was conducted by measuring the water inlet velocity and temperature fields by using a mobile robot equipped with high-quality sensors (Smrekar et al., 2006). The ambient air velocity as well as the air temperature and density in the vicinity of the cooling tower were measured. It was concluded that the optimal water/air mass flow ratio should be small and uniform across the entire area of the cooling tower. By keeping the water/air mass flow ratio constant, entropy generation, and thus exergy destruction, was minimized which resulted in lower outlet water temperature and greater efficiency of the cooling tower (Smrekar et al., 2006). Multi-objective optimization and experimental evaluation of a forced draft cooling tower using different fill options have been conducted (Singh and Das, 2016). The fills were wooden splash, wire mesh, and honeycomb. Objective functions for tower range (temperature difference between inlet water and outlet water), Merkel number, effectiveness, and evaporation rate were formulated using experimental data and then simultaneously optimized using genetic algorithm and different water and air flow rates. The most optimal combination of mass flow rates of water and air with wire mesh packing type provided a $5.8 \%$ increase in the effectiveness of the cooling tower as well as a $18.4 \%$ reduction in water consumption (Singh and Das, 2016).

\section{RESEARCH TREND}

Going through a comprehensive literature reviewing on cooling towers with the focus on water sustainability in the present study suggests the opportunity for mapping the completed studies. The authors present the conclusion of their 


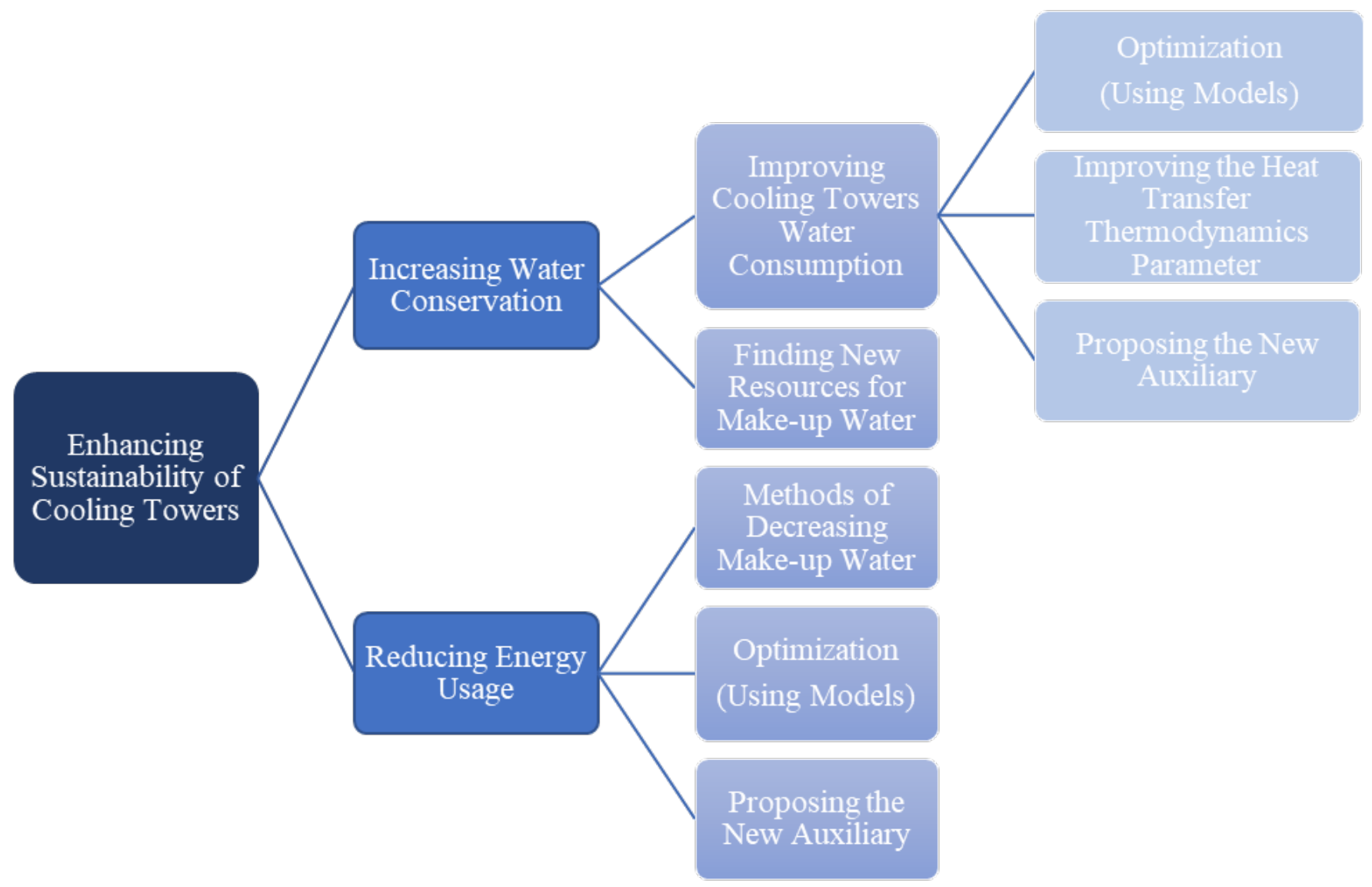

Figure 8. Research map for enhancing sustainability of cooling towers

study in the form of the research trends to facilitate the future study plans for advancing water conservations in cooling towers. Figure 8 illustrates the map of the research trend in advancing sustainability in wet cooling towers.

Finally, the proven effort for decreasing water usage in cooling towers from the past studies can be concluded as:

- Deploying cooling loops by reuse or recycle water (S.-Y. Pan et al., 2018),

- Changing wet cooling tower to hybrid or dry cooling tower (Deziani et al., 2017),

- Adding the dry cooling section to current wet cooling towers (S.-Y. Pan et al., 2018),

- Using air to air heat exchanger on the cooling tower (Deziani et al., 2017),

- Applying the airflow control method by taking advantage of fan VFD to reduce the water and energy consumption of cooling towers (S.-Y. Pan et al., 2018),

- Installing a RO water filtration system or other water filtering systems to reduce required blowdown (SchleiPeters et al., 2018),

- Reduction in blowdown with increasing of concentration cycles (Deziani et al., 2017),
- Decreasing pump power demand by installing a new pump motor for improved efficiency (Schlei-Peters et al., 2018),

- Reduction of the number of backwashing cycles (SchleiPeters et al., 2018),

- Changing the fan control mode to variable speed with parallel fan combination (Schlei-Peters et al., 2018).

\section{CONCLUSIONS}

Considering the dependency of life to water and its scarcity reveals the urgency of studying on reducing water consumption in the cooling towers since cooling towers are the gate for the invisible dissipation of water. The present study elaborated on the roles of cooling towers in cooling cycles while narrated the history of energy-water modeling methods of cooling towers through the Markel, the Poppe, and the Effectiveness-(NTU) Models since water and energy are deeply connected in cooling towers. The major classifications and configurations of cooling towers showed the wet cooling towers consume the highest water while dry cooling towers use the minimum water in a trade-off with performance. The hybrid cooling towers have the advantages of both while they are more costly. The past challenges for boosting water 
conservation in cooling towers were allocated in focusing on water supply sources or modifications of the cooling tower. There are some practical approaches to reduce the environmental impact of cooling towers such as using VFD, adding a dry section, and employing water filtration to reduce its water and energy consumption. Finally, the trend of future studies presents the potential investigations for water and energy reduction opportunities in the light of water-energy nexus. Proposing the new auxiliary equipment, finding methods of decreasing make-up water, and optimization of the energy models are the major path for future investigation to reduce energy consumption in cooling towers. Similarly, optimizing cooling towers water consumption, improving the heat transfer parameters in cooling towers, proposing the new auxiliary equipment, and findings new make-up water resources are future paths for boosting water conservations in cooling towers.

Author contributions: All co-authors have involved in all stages of this study while preparing the final version. They all agree with the results and conclusions.

Funding: The study received financial support from the Navy SMART graduate scholarship, and the University of Idaho, College of Engineering Graduate Student Funds, The Col. James and Col. Betty Lee Raymer Endowment for Learning.

Declaration of interest: The authors declare that they have no competing interests.

Ethics approval and consent to participate: Not applicable.

Availability of data and materials: All data generated or analyzed during this study are available for sharing when appropriate request is directed to corresponding author.

\section{REFERENCES}

Advocates, W. (2008). A Sustainable Path: Meeting Nevada's Water and Energy Demands (Boulder, CO: Western Resource Advocates).

Askari, S., Lotfi, R., Seifkordi, A., Rashidi, A. M. and Koolivand, H. (2016). A novel approach for energy and water conservation in wet cooling towers by using MWNTs and nanoporous graphene nanofluids. Energy Conversion and Management, 109, 10-18. https://doi.org/10.1016/ J.ENCONMAN.2015.11.053

Asvapoositkul, W. and Kuansathan, M. (2014). Comparative evaluation of hybrid (dry/wet) cooling tower performance. Applied Thermal Engineering, 71(1), 83-93. https://doi.org/10.1016/j.applthermaleng.2014.06.023

Ayoub, A., Gjorgiev, B. and Sansavini, G. (2018). Cooling towers performance in a changing climate: Technoeconomic modeling and design optimization. Energy, 160, 1133-1143. https://doi.org/10.1016/j.energy.2018.07.080

Botermans, R. and Smith, P. (2008). Cooling Towers. In Advanced Piping Design (pp. 177-182). https://doi.org/10.1016/B978-1-933762-18-0.50016-7

Bourillot, C. (1983). Hypotheses of calculation of the water flow rate evaporated in a wet cooling tower. https://www.osti.gov/biblio/5350107

Braun, J. E. (1988). Methodologies for the Design and Control of Central Cooling Plants. University of Wisconsin - Madison.
Braun, J., Klein, S. and JW Mitchell -. (1989). Effictiveness models for cooling towers and cooling coils. ASHRAE Transactions, 95.

Chang, C. C., Shieh, S. S., Jang, S. S., Wu, C. W. and Tsou, Y. (2015). Energy conservation improvement and ON-OFF switch times reduction for an existing VFD-fan-based cooling tower. Applied Energy, 154, 491-499. https://doi.org/10.1016/j.apenergy.2015.05.025

Chang, T.-B. and Lin, T.-M. (2016). Water and energy conservation for a counterflow cooling tower using UV light disinfection and variable speed fan. Proceedings of the Institution of Mechanical Engineers, Part E: Journal of Process Mechanical Engineering, 230(3), 235-243. https://doi.org/10.1177/0954408914546358

Ciferno, J., Munson, R., Murphy, J., Power, B. L.- and 2010, U. (2010). Determining Carbon Capture and Sequestration's Water Demands. Power, 154(3), 71-76.

Conradie, A. E. and Kröger, D. G. (1996). Performance evaluation of dry-cooling systems for power plant applications. Applied Thermal Engineering, 16(3), 219-232. https://doi.org/10.1016/1359-4311(95)00068-2

Cortinovis, G. F., Paiva, J. L., Song, T. W. and Pinto, J. M. (2009). A systemic approach for optimal cooling tower operation. Energy Conversion and Management, 50(9), 22002209. https://doi.org/10.1016/J.ENCONMAN.2009.04.033

CS Robinson. (1923). The design of cooling towers. Mech Eng, 15, 99-102.

Damak, M. and Varanasi, K. K. (2018). Electrostatically driven fog collection using space charge injection. Science Advances, 4(6), eaao5323. https://doi.org/10.1126/ sciadv.aao5323

Deziani, M., Rahmani, K., Mirrezaei Roudaki, S. J. and Kordloo, M. (2017). Feasibility study for reduce water evaporative loss in a power plant cooling tower by using air to Air heat exchanger with auxiliary Fan. Desalination, 406, 119-124. https://doi.org/10.1016/j.desal.2015.12.007

Dhorat, A., Al-Obaidi, M. A. and Mujtaba, I. M. (2019). Dynamic modelling and operational optimisation of natural draft cooling towers. Thermal Science and Engineering Progress, 9, 30-43. https://doi.org/10.1016/ j.tsep.2018.10.013

Duniam, S., Jahn, I., Hooman, K., Lu, Y. and Veeraragavan, A. (2018). Comparison of direct and indirect natural draft dry cooling tower cooling of the sCO 2 Brayton cycle for concentrated solar power plants. Applied Thermal Engineering, 130, 1070-1080. https://doi.org/10.1016/ j.applthermaleng.2017.10.169

García Cutillas, C., Ruiz Ramírez, J. and Lucas Miralles, M. (2017). Optimum Design and Operation of an HVAC Cooling Tower for Energy and Water Conservation. Energies, 10(3), 299. https://doi.org/10.3390/en10030299

Ghosh, R. and Ganguly, R. (2018). Harvesting Water from Natural and Industrial Fogs-Opportunities and Challenges (pp. 237-266). https://doi.org/10.1007/978-981-10-72338_9 
Ghosh, R. and Ganguly, R. (2019). Fog harvesting from cooling towers using metal mesh: Effects of aerodynamic, deposition, and drainage efficiencies. J Power and Energy. https://doi.org/10.1177/0957650919890711

Ghosh, R., Patra, C., Singh, P., Ganguly, R., Sahu, R. P., Zhitomirsky, I. and Puri, I. K. (2020). Influence of metal mesh wettability on fog harvesting in industrial cooling towers. Applied Thermal Engineering, 181, 115963. https://doi.org/10.1016/j.applthermaleng.2020.115963

Ghosh, R., Ray, T. K. and Ganguly, R. (2015). Cooling tower fog harvesting in power plants e A pilot study. Energy, 1-11. https://doi.org/10.1016/j.energy.2015.06.050

Gilani, N., Doustani Hendijani, A. and Shirmohammadi, R. (2019). Developing of a novel water-efficient configuration for shower cooling tower integrated with the liquid desiccant cooling system. Applied Thermal Engineering, 154, 180-195. https://doi.org/10.1016/j.applthermaleng. 2019.03.043

Gilani, N. and Parpanji, F. (2017). Parametric study on the outlet water temperature in a shower cooling tower and its application in different Iranian provincial capitals. International Journal of Thermal Sciences, 124, 174-186. https://doi.org/10.1016/j.ijthermalsci.2017.10.017

Golkar, B., Naserabad, S. N., Soleimany, F., Dodange, M., Ghasemi, A., Mokhtari, H. and Oroojie, P. (2019). Determination of optimum hybrid cooling wet/dry parameters and control system in off design condition: Case study. Applied Thermal Engineering, 149, 132-150. https://doi.org/10.1016/j.applthermaleng.2018.12.017

Gololo, K. V and Majozi, T. (2012). Complex Cooling Water Systems Optimization with Pressure Drop Consideration. Industrial \& Engineering Chemistry Research, Special Issue. https://doi.org/10.1021/ie302498j

González Pedraza, O. J., Pacheco Ibarra, J. J., Rubio-Maya, C., Galván González, S. R. and Rangel Arista, J. A. (2018). Numerical study of the drift and evaporation of water droplets cooled down by a forced stream of air. Applied Thermal Engineering, 142, 292-302. https://doi.org/ 10.1016/j.applthermaleng.2018.07.011

Grange, J. L. (1994). Calculating the evaporated water flow in a wet cooling tower.

Grobbelaar, P. J., Reuter, H. C. R. and Bertrand, T. P. (2013). Performance characteristics of a trickle fill in cross- and counter-flow configuration in a wet-cooling tower. Applied Thermal Engineering, 50, 475e484. https://doi.org/10.1016/ j.applthermaleng.2012.06.026

Guerras, L. S. and Martín, M. (2020). On the water footprint in power production: Sustainable design of wet cooling towers. Applied Energy, 263. https://doi.org/10.1016/ j.apenergy.2020.114620

Guo, Y., Wang, F., Jia, M. and Zhang, S. (2017). Parallel hybrid model for mechanical draft counter flow wet-cooling tower Parallel hybrid model for mechanical draft counter flow wet-cooling tower. Applied Thermal Engineering, 125, 13791388.

https://doi.org/10.1016/j.applthermaleng.2017.07.138
Hajidavalloo, E., Shakeri, R. and Mehrabian, M. A. (2010). Thermal performance of cross flow cooling towers in variable wet bulb temperature. Energy Conversion and Management, 51, 1298-1303. https://doi.org/10.1016/ j.enconman.2010.01.005

Hansen, E., Rodrigues, M. A. S. and Aquim, P. M. de. (2016). Wastewater reuse in a cascade based system of a petrochemical industry for the replacement of losses in cooling towers. Journal of Environmental Management, 181, 157-162. https://doi.org/10.1016/j.jenvman.2016.06.014

Hassler, R. (1999). Einfluss von Kondensation in der Grenzschicht auf die Waerme-und Stoffuebertragung an einem Rieselfilm. In VDI VERLAG.

He, S., Gurgenci, H., Guan, Z. and Alkhedhair, A. M. (2013). Pre-cooling with Munters media to improve the performance of Natural Draft Dry Cooling Towers. Applied Thermal Engineering, 53(1), 67-77. https://doi.org/10.1016/ j.applthermaleng.2012.12.033

Hernández-Calderón, O. M., Rubio-Castro, E. and Rios-Iribe, E. Y. (2014). Solving the heat and mass transfer equations for an evaporative cooling tower through an orthogonal collocation method. Computers and Chemical Engineering, 71, 24-38. https://doi.org/10.1016/j.compchemeng.2014. 06.008

Hooman, K. (2010). Dry cooling towers as condensers for geothermal power plants. International Communications in Heat and Mass Transfer, 37(9), 1215-1220. https://doi.org/10.1016/j.icheatmasstransfer.2010.07.011

Hu, H., Li, Z., Jiang, Y. and Du, X. (2018). Thermodynamic characteristics of thermal power plant with hybrid (dry/wet) cooling system. Energy, 147, 729-741. https://doi.org/10.1016/j.energy.2018.01.074

Huang, X., Li, Y., Ke, T., Ling, X. and Liu, W. (2017). Thermal investigation and performance analysis of a novel evaporation system based on a humidificationdehumidification process. Energy Conversion and Management, 147, 108-119. https://doi.org/10.1016/ j.enconman.2017.05.036

Hughes, B. R., Chaudhry, H. N. and Ghani, S. A. (2011). A review of sustainable cooling technologies in buildings. Renewable and Sustainable Energy Reviews, 15(6), 31123120. https://doi.org/10.1016/j.rser.2011.03.032

Imani-Mofrad, P., Saeed, H. and Shanbedi, M. (2016). Experimental investigation of filled bed effect on the thermal performance of a wet cooling tower by using $\mathrm{ZnO} /$ water nanofluid. Energy Conversion and Management, 127, 199-207. https://doi.org/10.1016/j.enconman.2016. 09.009

Irok, B., Blagojevi, B., Novak, M., Hoevar, M. and Jere and F. (2003). Energy and Mass Transfer Phenomena in Natural Draft Cooling Towers. Heat Transfer Engineering, 24(3), 6675. https://doi.org/10.1080/01457630304061

Isozumi, R., Ito, Y., Ito, I., Osawa, M., Hirai, T., Takakura, S., Iinuma, Y., Ichiyama, S., Tateda, K., Yamaguchi, K. and Mishima, M. (2005). An outbreak of Legionella pneumonia originating from a cooling tower. Scandinavian Journal of Infectious Diseases, 37, 709-711. https://doi.org/10.1080/ 00365540510012143 
Jaber, H. and Webb, R. L. (1989). Design of cooling towers by the effectiveness-NTU method. Journal of Heat Transfer, 111(4), 837-843. https://doi.org/10.1115/1.3250794

James, R. E., Kearins, D., Turner, M., Woods, M., Kuehn, N. and Zoelle, A. (2010). Cost and Performance Baseline for Fossil Energy Plants Volume 1: Bituminous Coal and Natural Gas to Electricity Revision 2. https://doi.org/10.2172/1569246

Jes', J., Ortiz-Del-Castillo, J. R., Hernándezhern'hernándezCalderón, O. M., Calderón, C., Rios-Iribe, E. Y., Gonzálezgonz'gonzález-Llanes, M. D., Rubio-Castro, E. and Cervantes-Gaxiola, M. E. (2019). Analytical solution of the governing equations for heat and mass transfer in evaporative cooling process. International Journal of Refrigeration, 111, 178-187. https://doi.org/10.1016/ j.ijrefrig.2019.11.019

Jin, G.-Y., Cai, W.-J., Lu, L., Lock Lee, E. and Chiang, A. (2007). A simplified modeling of mechanical cooling tower for control and optimization of HVAC systems. Energy Conversion and Management, 48, 355-365. https://doi.org/10.1016/j.enconman.2006.07.010

Ke, T., Huang, X. and Ling, X. (2019). Numerical and experimental analysis on air/water direct contact heat and mass transfer in the humidifier. Applied Thermal Engineering, 156, 310-323. https://doi.org/10.1016/ j.applthermaleng.2019.04.051

Keshtkar, M. M. and Mehdi Keshtkar, M. (2016). Performance Analysis of a Counter Flow Wet Cooling Tower and Selection of Optimum Operative Condition by MCDMTOPSIS Method. Applied Thermal Engineering. https://doi.org/10.1016/j.applthermaleng.2016.12.043

Khamis Mansour, M. and Hassab, M. A. (2014). Innovative correlation for calculating thermal performance of counterflow wet-cooling tower. Energy, 74(C), 855-862. https://doi.org/10.1016/j.energy.2014.07.059

Khan, J. U. R., Qureshi, B. A. and Zubair, S. M. (2004). A comprehensive design and performance evaluation study of counter flow wet cooling towers. International Journal of Refrigeration, 27(8), 914-923. https:/doi.org/10.1016/ j.ijrefrig.2004.04.012

Kim, H., Rao, S. R., LaPotin, A., Lee, S. and Wang, E. N. (2020). Thermodynamic analysis and optimization of adsorptionbased atmospheric water harvesting. International Journal of Heat and Mass Transfer, 161, 120253. https://doi.org/10.1016/j.ijheatmasstransfer.2020.120253

King, C. W., Stillwell, A. S., Twomey, K. M. and Webber, M. E. (2013). Coherence between Water and Energy Policies. Natural Resources Journal, 53.

Klimanek, A. and Białecki, R. A. (2009). Solution of heat and mass transfer in counterflow wet-cooling tower fills. International Communications in Heat and Mass Transfer, 36, 547-553. https://doi.org/10.1016/j.icheatmasstransfer. 2009.03.007

Kloppers, Johannes C. and Kröger, D. G. (2005). The Lewis factor and its influence on the performance prediction of wet-cooling towers. International Journal of Thermal Sciences, 44(9), 879-884. https://doi.org/10.1016/ j.ijthermalsci.2005.03.006
Kloppers, Johannes C and Krö Ger, D. G. (2005). Cooling Tower Performance Evaluation: Merkel, Poppe, and e-NTU Methods of Analysis. Journal of Engineering for Gas Turbines and Power, 127(1), 1-7. https://doi.org/10.1115/1.1787504

Kloppers, Johannes Christiaan. (2003). A critical evaluation and refinement of the performance prediction of wet-cooling towers [University of Stellenbosch]. http://scholar. sun.ac.za/handle/10019.1/1476

Kranc, S. C. (2007). Optimal spray patterns for counterflow cooling towers with structured packing. Applied Mathematical Modelling, 31, 676-686. https://doi.org/ 10.1016/j.apm.2005.11.027

Kurnik, C. W., Boyd, B., Stoughton, K. M. and Lewis, T. (2017). Cooling Tower (Evaporative Cooling System) Measurement and Verification Protocol. https://doi.org/10.2172/1412805

LEWIS and K., W. (1922). The evaporation of a liquid into a gas. Trans. ASME., 44, 325-340.

Li, X., Gurgenci, H., Guan, Z., Wang, X. and Duniam, S. (2017). Measurements of crosswind influence on a natural draft dry cooling tower for a solar thermal power plant. Applied Energy, 206, 1169-1183. https://doi.org/10.1016/ j.apenergy.2017.10.038

Li, Y., Huang, X., Peng, H., Ling, X. and Tu, S. (2017). Energy Simulation and optimization of humidificationdehumidification evaporation system. Energy, 145, 128140. https://doi.org/10.1016/j.energy.2017.12.119

Liao, J., Xie, X., Nemer, H., Claridge, D. E. and Culp, C. H. (2019). A simplified methodology to optimize the cooling tower approach temperature control schedule in a cooling system. Energy Conversion and Management, 199, 111950. https://doi.org/10.1016/j.enconman.2019.111950

Lindahl, P. A. J. and Jameson, R. W. (1995). Plume abatement and water conservation with the wet/dry cooling tower (Technical Report) I OSTI.GOV. https://www.osti.gov/biblio/48147

Liu, S., Song, J., Shi, J. and Yang, B. (2019). An improved seriesparallel optimization approach for cooling water system. Applied Thermal Engineering, 154, 368-379. https://doi.org/ 10.1016/J.APPLTHERMALENG.2019.03.048

Llano-Restrepo, M. and Monsalve-Reyes, R. (2016). Modeling and simulation of counterflow wet-cooling towers and the accurate calculation and correlation of mass transfer coefficients for thermal performance prediction. International Journal of Refrigeration, 74, 47-72. https://doi.org/10.1016/j.ijrefrig.2016.10.018

Lucas, M., Martínez, P. J. and Viedma, A. (2009). Experimental study on the thermal performance of a mechanical cooling tower with different drift eliminators. Energy Conversion and Management, 50(3), 490-497. https://doi.org/ 10.1016/j.enconman.2008.11.008

M Roth. (2001). Fundamentals of heat and mass transfer in wet cooling towers. All well known or are further developments necessary? Proceedings of 12th IAHR Cooling Tower and Heat Exchangers. 
Ma, H., Si, F., Zhu, K. and Wang, J. (2018). The adoption of windbreak wall partially rotating to improve thermo-flow performance of natural draft dry cooling tower under crosswind. International Journal of Thermal Sciences, 134, 66-88. https://doi.org/10.1016/j.ijthermalsci.2018.08.005

Mantelli, M. H. B. (2016). Development of porous media thermosyphon technology for vapor recovering in crosscurrent cooling towers. Applied Thermal Engineering, 108, 398-413.

https://doi.org/10.1016/j.applthermaleng.2016.07.144

Marmouch, H., Orfi, J. and Nasrallah, S. Ben. (2009). Experimental study of the performance of a cooling tower used in a solar distiller. Desalination, 250, 456-458. https://doi.org/10.1016/j.desal.2009.09.073

Martin, A. D., Herzog, H. J. and Clark, J. P. (2012). Water Footprint of Electric Power Generation: Modeling its use and analyzing options for a water-scarce future L._LBRA RIES ARCHivES. https://dspace.mit.edu/handle/1721.1/72886

Meldrum, J., Nettles-Anderson, S., Heath, G. and Macknick, J. (2013). Life cycle water use for electricity generation: a review and harmonization of literature estimates. Environmental Research Letters, 8. https://doi.org/ 10.1088/1748-9326/8/1/015031

Merkel, F., VDI-Verlag, V. V.-, Berlin, undefined, \& 1925, undefined. (1925). Forschungsarbeiten No. 275.

Meroney, R. N. (2006). CFD prediction of cooling tower drift. Journal of Wind Engineering and Industrial Aerodynamics, 94, 463-490. https://doi.org/10.1016/j.jweia.2006.01.015

Michioka, T., Sato, A., Kanzaki, T. and Sada, K. (2007). Wind tunnel experiment for predicting a visible plume region from a wet cooling tower. Journal of Wind Engineering and Industrial Aerodynamics, 95, 741-754. https://doi.org/ 10.1016/j.jweia.2007.01.005

Mishra, B., Srivastava, A. and Yadav, L. (2019). Performance analysis of cooling tower using desiccant. Heat and Mass Transfer, 56, 1153-1169. https://doi.org/10.1007/s00231019-02759-y

Muangnoi, T., Asvapoositkul, W. and Hungspreugs, P. (2014). Performance characteristics of a downward spray water-jet cooling tower. Applied Thermal Engineering, 69(1-2), 165176. https://doi.org/10.1016/J.APPLTHERMALENG.2014. 04.019

Muangnoi, T., Asvapoositkul, W. and Wongwises, S. (2006). An exergy analysis on the performance of a counterflow wet cooling tower. Applied Thermal Engineering, 27, 910-917. https://doi.org/10.1016/j.applthermaleng.2006.08.012

Naphon, P. (2005). Study on the heat transfer characteristics of an evaporative cooling tower. International Communications in Heat and Mass Transfer, 32(8), 10661074. https://doi.org/10.1016/J.ICHEATMASSTRANSFER. 2005.05.016

Nasrabadi, M. and Finn, D. P. (2014a). Mathematical modeling of a low temperature low approach direct cooling tower for the provision of high temperature chilled water for conditioning of building spaces. Applied Thermal Engineering, 64, 273-282. https://doi.org/10.1016/ j.applthermaleng.2013.12.025
Nasrabadi, M. and Finn, D. P. (2014b). Performance analysis of a low approach low temperature direct cooling tower for high-temperature building cooling systems. Energy and Buildings, 84, 674-689. https://doi.org/10.1016/ j.enbuild.2014.09.019

Nourani, Z., Naserbegi, A., Tayyebi, S. and Aghaie, M. (2019). Thermodynamic evaluation of hybrid cooling towers based on ambient temperature. Thermal Science and Engineering Progress, 14. https://doi.org/10.1016/j.tsep.2019.100406

Pan, S.-Y., Snyder, S. W., Packman, A. I., Lin, Y. J. and Chiang, P.-C. (2018). Cooling water use in thermoelectric power generation and its associated challenges for addressing water-energy nexus. Water-Energy Nexus, 1(1), 26-41. https://doi.org/10.1016/j.wen.2018.04.002

Pan, T.-H., Shieh, S.-S., Jang, S.-S., Tseng, W.-H., Wu, C.-W. and Ou, J.-J. (2011). Statistical multi-model approach for performance assessment of cooling tower. Energy Conversion and Management, 52, 1377-1385. https://doi.org/10.1016/j.enconman.2010.09.036

Pan, T., Xu, D., Li, Z., Shieh, S.-S. and Jang, S.-S. (2013). Efficiency improvement of cogeneration system using statistical model. Energy Conversion and Management, 68, 169-176. https://doi.org/10.1016/j.enconman.2012.12.026

Panjeshahi, M. H., Ataei, A., Gharaie, M. and Parand, R. (2009). Optimum design of cooling water systems for energy and water conservation. Chemical Engineering Research and Design, 87(2), 200-209. https://doi.org/10.1016/ J.CHERD.2008.08.004

Papaefthimiou, V. D., Zannis, T. C. and Rogdakis, E. D. (2006). Thermodynamic study of wet cooling tower performance. International Journal of Energy Research, 30(6), 411-426. https://doi.org/10.1002/er.1158

Peer, R. A. and Sanders, K. T. (2017). The water consequences of a transitioning US power sector. Applied Energy, 210, 613-622. https://doi.org/10.1016/j.apenergy.2017.08.021

Picardo, J. R. and Variyar, J. E. (2012). The Merkel equation revisited: A novel method to compute the packed height of a cooling tower. Energy Conversion and Management, 57, 167-172. https://doi.org/10.1016/j.enconman.2011.12.016

Picón-Núnez, M., Polley, G. T., Canizalez-Dávalos, L., Martín Medina-Flores, J., Norte, U., Juan Alonso, L. and Gto, C. (2011). Short cut performance method for the design of flexible cooling systems. Energy, 36, 46464653. https://doi.org/10.1016/j.energy.2011.04.041

Pontes, R. F. F., Yamauchi, W. M. and Silva, E. K. G. (2019). Analysis of the effect of seasonal climate changes on cooling tower efficiency, and strategies for reducing cooling tower power consumption. Applied Thermal Engineering, 161, 114148. https://doi.org/10.1016/ j.applthermaleng.2019.114148

Poppe, M. and H Rögener -. (1991). Berechnung von rückkühlwerken. In Springer Berlin.

Pozzobon, J. C., Mantelli, M. B. H. and Da Silva, A. K. (2016). Experimental study of unstructured porous media inserts for water recovery in a reduced scale, crossflow cooling tower. Applied Thermal Engineering, 96, 632-639. https://doi.org/10.1016/j.applthermaleng.2015.11.039 
Qi, X., Liu, Y., Guo, Q., Yu, J. and Yu, S. (2016). Performance prediction of seawater shower cooling towers. Energy, 97, 435-443. https://doi.org/10.1016/j.energy.2015.12.125

Qi, X. and Liu, Z. (2008). Further investigation on the performance of a shower cooling tower. Energy Conversion and Management, 49, 570-577. https://doi.org/10.1016/ j.enconman.2007.07.038

Rahmani, K. (2017). Reducing water consumption by increasing the cycles of concentration and Considerations of corrosion and scaling in a cooling system. Applied Thermal Engineering, 114, 849-856. https://doi.org/ 10.1016/J.APPLTHERMALENG.2016.12.075

Rao, R. V and Patel, V. K. (2011). Optimization of mechanical draft counter flow wet-cooling tower using artificial bee colony algorithm. Energy Conversion and Management, 52, 2611-2622.

https://doi.org/10.1016/j.enconman.2011.02.010

RD Mitchell. (1989). Survey of water-conserving heat rejection systems. https://www.osti.gov/biblio/6183566

Ren, C. (2006). An Analytical Approach to the Heat and Mass Transfer Processes in Counterflow Cooling Towers. J. Heat Transfer, 128(11), 1142-1148. https://doi.org/10.1115/ 1.2352780

Ren, C. Q. (2008). Corrections to the simple effectiveness-NTU method for counterflow cooling towers and packed bed liquid desiccant-air contact systems. International Journal of Heat and Mass Transfer, 51(1-2), 237-245. https://doi.org/10.1016/j.ijheatmasstransfer.2007.04.028

Rezaei, E., Shafiei, S. and Abdollahnezhad, A. (2010). Reducing water consumption of an industrial plant cooling unit using hybrid cooling tower. Energy Conversion and Management, 51(2), 311-319. https://doi.org/10.1016/ j.enconman.2009.09.027

Rubio-Castro, E., Serna-González, M., Ponce-Ortega, J. M. and Morales-Cabrera, M. A. (2011). Optimization of mechanical draft counter flow wet-cooling towers using a rigorous model. Applied Thermal Engineering, 31(16), 3615-3628. https://doi.org/10.1016/j.applthermaleng.2011.07.029

Sanders, K. T. (2015). Critical Review: Uncharted Waters? The Future of the Electricity-Water Nexus. Environ. Sci. Technol, 49, 51-66. https://doi.org/10.1021/es504293b

Sarker, M. M. A., Shim, G. J., Lee, H. S., Moon, C. G. and Yoon, J. I. (2009). Enhancement of cooling capacity in a hybrid closed circuit cooling tower. Applied Thermal Engineering, 29(16), 3328-3333. https://doi.org/10.1016/j.appltherma leng.2009.05.012

Scanlon, B. R., Reedy, R. C., Duncan, I., Mullican, W. F. and Young, M. (2013). Controls on water use for thermoelectric generation: Case study Texas, U.S. Environmental Science and Technology, 47(19), 11326-11334. https://doi.org/ 10.1021/es4029183

Schlei-Peters, I., Wichmann, M. G., Matthes, I.-G., Gundlach, F.-W. and Spengler, T. S. (2018). Integrated Material Flow Analysis and Process Modeling to Increase Energy and Water Efficiency of Industrial Cooling Water Systems. Journal of Industrial Ecology, 22(1), 41-54. https://doi.org/10.1111/jiec.12540
Sesma Martín, D. and Rubio-Varas, M. del M. (2017). Freshwater for Cooling Needs: A Long-Run Approach to the Nuclear Water Footprint in Spain. Ecological Economics, 140, 146-156. https://doi.org/10.1016/j.ecolecon.2017.04. 032

Sharqawy, M. H., Al-Shalawi, I., Antar, M. A. and Zubair, S. M. (2017). Experimental investigation of packed-bed crossflow humidifier. Applied Thermal Engineering, 117, 584590.

https://doi.org/10.1016/j.applthermaleng.2017.02.061

Sharqawy, M. H., Lienhard V, J. H. and Zubair, S. M. (2011). On thermal performance of seawater cooling towers. Journal of Engineering for Gas Turbines and Power, 133(4). https://doi.org/10.1115/1.4002159

Shuster, E. (2007). Estimating freshwater needs to meet future thermoelectric generation requirements (2007 update). National Energy Technology Laboratory.

Singh, K. and Das, R. (2016). An experimental and multiobjective optimization study of a forced draft cooling tower with different fills. Energy Conversion and Management, 111, 417-430. https://doi.org/10.1016/J.ENCONMAN.2015. 12.080

Singh, K. and Das, R. (2017). Simultaneous optimization of performance parameters and energy consumption in induced draft cooling towers. Chemical Engineering Research and Design, 123, 1-13. https://doi.org/ 10.1016/j.cherd.2017.04.031

Singla, R. K., Singh, K. and Das, R. (2016). Tower characteristics correlation and parameter retrieval in wetcooling tower with expanded wire mesh packing. Applied Thermal Engineering, 96, 240-249. https://doi.org/10.1016/ j.applthermaleng.2015.11.063

Smrekar, J., Kuštrin, I. and Oman, J. (2011). Methodology for evaluation of cooling tower performance- Part 1: Description of the methodology. Energy Conversion and Management, 52, 3257-3264. https://doi.org/10.1016/ j.enconman.2011.05.005

Smrekar, J., Oman, J. and Širok, B. (2006). Improving the efficiency of natural draft cooling towers. Energy Conversion and Management, 47(9-10), 1086-1100. https://doi.org/10.1016/J.ENCONMAN.2005.07.012

Söylemez, M. S. (2004). On the optimum performance of forced draft counter flow cooling towers. Energy Conversion and Management, 45(15-16), 2335-2341. https://doi.org/ 10.1016/j.enconman.2003.11.023

Stahl, E., Ziemann, S., Galliher, W., Wiebe, P., Gauley, B. and Williams, A. (2015). Final Literature Review on Best Practices of Water Conservation \& Efficiency. In City of Guelph.

Streng, A. (1998). Combined Wet/Dry Cooling Towers of CellType Construction. Journal of Energy Engineering, 124(3), 104-121. https://doi.org/10.1061/(ASCE)0733-9402(1998) $124: 3(104)$

Suppes, G. and Truman, S. (2007). Production of Electricity. In Sustainable Nuclear Power (pp. 185-200). https://doi.org/10.1016/b978-012370602-7/50024-7 
Sutherland, J. (1983). Analysis of mechanical-draught counterflow air/water cooling towers. J. Heat Transfer, 105(3), 576-583. https://doi.org/10.1115/1.3245624

Taghian Dehaghani, S. and Ahmadikia, H. (2017). Retrofit of a wet cooling tower in order to reduce water and fan power consumption using a wet/dry approach. Applied Thermal Engineering, 125, 1002-1014. https:/doi.org/10.1016/ J.APPLTHERMALENG.2017.07.069

Tyagi, S. K., Pandey, A. K., Pant, P. C. and Tyagi, V. V. (2012). Formation, potential and abatement of plume from wet cooling towers: A review. Renewable and Sustainable Energy Reviews, 16(5), 3409-3429. https://doi.org/10.1016/ j.rser.2012.01.059

Tyagi, S. K., Wang, S. and Ma, Z. (2007). Prediction, potential and control of plume from wet cooling tower of commercial buildings in Hong Kong: A case study. International Journal of Energy Research, 31(8), 778-795. https://doi.org/ 10.1002/er.1269

Tyagi, S. K., Wang, S., Park, S. R., Sharma, A. and Kong, H. (2008). Economic considerations and cost comparisons between the heat pumps and solar collectors for the application of plume control from wet cooling towers of commercial buildings. Renewable and Sustainable Energy Reviews, 12, 2194-2210. https://doi.org/10.1016/j.rser. 2007.03.012

Uzgoren, E. and Timur, E. (2015). A methodology to assess suitability of a site for small scale wet and dry CSP systems. International Journal of Energy Research, 39(8), 1094-1108. https://doi.org/10.1002/er.3314

Wang, J.-G., Shieh, S.-S., Jang, S.-S. and Wu, C.-W. (2013). Discrete model-based operation of cooling tower based on statistical analysis. https://doi.org/10.1016/j.enconman. 2013.04.025

Wang, Y., Wang, L., Huang, Q. and Cui, Y. (2015). Experimental and theoretical investigation of cross-flow heat transfer equipment for air energy high efficient utilization $\mathrm{A}$ Combined Experimental and Theoretical Investigation for Cross-flow Heat-collecting Equipment. Applied Thermal Engineering, 98, 1231-1240. https://doi.org/10.1016/ j.applthermaleng.2015.12.129

Wei, H., Du, X., Yang, L. and Yang, Y. (2017). Entransy dissipation based optimization of a large-scale dry cooling system. Applied Thermal Engineering, 125, 254-265. https://doi.org/10.1016/j.applthermaleng.2017.06.117
Wei, H., Huang, X., Chen, L., Yang, L. and Du, X. (2020). Performance prediction and cost-effectiveness analysis of a novel natural draft hybrid cooling system for power plants. Applied Energy, 262, 114555. https://doi.org/ 10.1016/j.apenergy.2020.114555

Williamson, N., Behnia, M. and Armfield, S. (2008). Comparison of a 2D axisymmetric CFD model of a natural draft wet cooling tower and a 1D model. International Journal of Heat and Mass Transfer, 51, 2227-2236. https://doi.org/10.1016/j.ijheatmasstransfer.2007.11.008

$\mathrm{Xu}, \mathrm{X}$., Wang, S. and Ma, Z. (2008). Evaluation of plume potential and plume abatement of evaporative cooling towers in a subtropical region. Applied Thermal Engineering, 28, 1471-1484. https://doi.org/10.1016/ j.applthermaleng.2007.09.003

Xu, Y.-J., Zhang, S.-J., Chi, J.-L. and Xiao, Y.-H. (2015). Steadystate off-design thermodynamic performance analysis of a SCCP system. Applied Thermal Engineering, 90, 221-231. https://doi.org/10.1016/j.applthermaleng.2015.06.092

Xuan, Y. M., Xiao, F., Niu, X. F., Huang, X. and Wang, S. W. (2012). Research and application of evaporative cooling in China: A review (I) - Research. Renewable and Sustainable Energy Reviews, 16, 3535-3546. https://doi.org/10.1016/ j.rser.2012.01.052

Yang, Y., Cui, G. and Lan, C. Q. (2019). Developments in evaporative cooling and enhanced evaporative cooling - A review. Renewable and Sustainable Energy Reviews, 113, 109230. https://doi.org/10.1016/j.rser.2019.06.037

Zavaragh, H. G., Ceviz, A. and Shervani Tabar, M. (2016). Analysis of windbreaker combinations on steam power plant natural draft dry cooling towers. Applied Thermal Engineering, 99, 550-559. https://doi.org/10.1016/ j.applthermaleng.2016.01.103

Zhai, H. and Rubin, E. S. (2010). Performance and cost of wet and dry cooling systems for pulverized coal power plants with and without carbon capture and storage. Energy Policy, 38(10), 5653-5660. https://doi.org/10.1016/j.enpol.2010. 05.013

Zhai, H., Rubin, E. S. and Versteeg, P. L. (2011). Water use at pulverized coal power plants with postcombustion carbon capture and storage. Environmental Science and Technology, 45(6), 2479-2485. https://doi.org/10.1021/es1034443

Zhou, Y., Zhu, X. and Ding, X. (2017). Theoretical investigation on thermal performance of new structure closed wet cooling tower. Heat Transfer Engineering, 39(5), 1-11. https://doi.org/10.1080/01457632.2017.1312899 